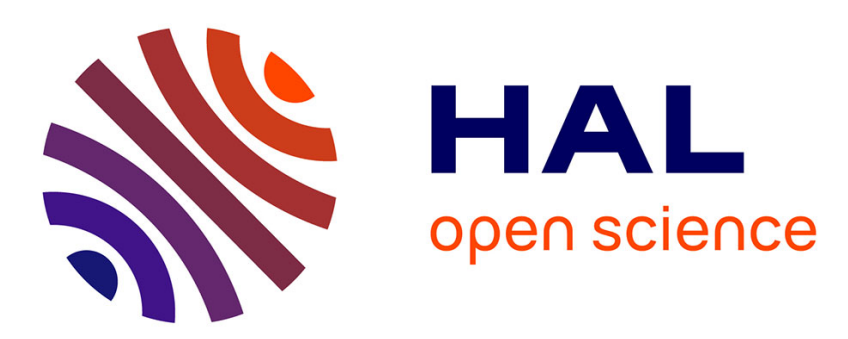

\title{
Chemical and in vitro characterizations of a promising bimodal AGuIX probe able to target apoptotic cells for applications in MRI and optical imaging
}

Mario Dentamaro, François Lux, Luce Vander Elst, Nicolas Dauguet, Sylvie Montante, Albert Moussaron, Carmen Burtea, Robert N. Muller, Olivier Tillement, Sophie Laurent

\section{To cite this version:}

Mario Dentamaro, François Lux, Luce Vander Elst, Nicolas Dauguet, Sylvie Montante, et al.. Chemical and in vitro characterizations of a promising bimodal AGuIX probe able to target apoptotic cells for applications in MRI and optical imaging. Contrast Media and Molecular Imaging, 2016, 11 (5), pp.381 - 395. 10.1002/cmmi.1702 . hal-01405753

\section{HAL Id: hal-01405753 https://hal.science/hal-01405753}

Submitted on 12 Feb 2021

HAL is a multi-disciplinary open access archive for the deposit and dissemination of scientific research documents, whether they are published or not. The documents may come from teaching and research institutions in France or abroad, or from public or private research centers.
L'archive ouverte pluridisciplinaire HAL, est destinée au dépôt et à la diffusion de documents scientifiques de niveau recherche, publiés ou non, émanant des établissements d'enseignement et de recherche français ou étrangers, des laboratoires publics ou privés. 


\title{
Chemical and in vitro characterizations of a promising bimodal AGuIX probe able to target apoptotic cells for applications in MRI and optical imaging
}

\author{
Mario Dentamaro ${ }^{a, b}, c_{*}$, François Lux ${ }^{b}$, Luce Vander Elst ${ }^{a, c}$, \\ Nicolas Dauguet ${ }^{\mathrm{d}}$, Sylvie Montante ${ }^{\mathrm{a}}$, Albert Moussaron ${ }^{\mathrm{e}}$, Carmen Burtea ${ }^{\mathrm{a}}$, \\ Robert N. Muller ${ }^{a, c}$, Olivier Tillement ${ }^{b}$ and Sophie Laurent ${ }^{a, c *}$
}

\begin{abstract}
Different studies on AGuIX nanoparticles have been achieved in the biomedical domain, showing that they allow us to combine multimodal and theranostic properties in oncology. The targeting of apoptotic cells presents a wide range of biomedical applications, including the monitoring of antitumoral therapy and the diagnosis of diseases related to this process, such as atherosclerosis, ischemia, chronic inflammation or autoimmune disorders. AGuIX nanoparticles functionalized with a peptide that recognizes apoptotic cells and with organic fluorophores were characterized by several physicochemical and biological methods such as HPLC, relaxometry and photon correlation spectroscopy, which attested to their potential as bimodal tracers detected by optical imaging and MRI. An increase of relaxivity and stability of AGuIX nanoparticles is also observed after their vectorization. The biological efficiency of this novel bimodal probe to target apoptotic cells was evaluated by fluorescence microscopy, relaxometry, MRI and flow cytometry on a lymphoblastic human T-cell line. In vitro cell apoptosis was chemically induced by incubation with camptothecin. Our in vitro experiments showed a significant specificity of vectorized AGulX nanoparticles for camptothecin-treated cells that suggests their potential efficiency as probes to target apoptosis. Copyright $\odot 2016$ John Wiley \& Sons, Ltd.

Additional supporting information may be found in the online version of this article at the publisher's web site.
\end{abstract}

Keywords: nanoparticles; AGuIX; paramagnetic; fluorescence; apoptosis; MRI; imaging

\section{INTRODUCTION}

During recent years, outstanding research has led to the synthesis of more efficient contrast agents for pre-clinical imaging. Paramagnetic AGuIX nanoparticles are one of these new probes for medical applications (1). These paramagnetic ultrasmall rigid platforms (SRPs) have the peculiarity to include on their surface several functions allowing coupling reactions with different compounds (MRI contrast agents, fluorophores, chelators for labelling by radioisotopes, biological vectors, ...). Therefore, AGulX nanoparticles appear as a possible multimodal nanoplatform, with the possibility to combine molecules and allow their detection by several imaging techniques such as magnetic resonance imaging (MRI), optical imaging or therapeutic applications such as radiosensitization or photodynamic therapy $(2,3)$.

Paramagnetic AGuIX nanoparticles are composed by a polysiloxane network synthesized from hydrolysis condensation of tetraethylorthosilicate (TEOS, 40\%) and aminopropyltriethoxysilane (APTES, 60\%). APTES allows the presence of some amine functions as potential coupling sites for Gd-DOTA derivatives. Potentiometric titrations showed that $\mathrm{Gd}^{\text {III }}$ ions are strongly chelated to DOTA compounds (complexation constant $\log \beta_{110}=24.78$ (4), very close to that of DOTAREM ${ }^{\circledR}, \log \beta_{110}=25.58$ ).

Proton relaxation measurements of AGulX suspensions have shown a high longitudinal relaxivity ${ }^{1}$ of $11.9 \mathrm{~s}^{-1} \mathrm{mM}^{-1}$ of $\mathrm{Gd}$ at
$60 \mathrm{MHz}$ and $37^{\circ} \mathrm{C}$. Moreover, they have an excellent biocompatibility, with a low cytotoxicity confirmed by cellular tests $(1,4)$. Because of their small hydrodynamic diameter $(<5 \mathrm{~nm})$, they are easily excreted via the renal system. In fact, injection of mice with different $\mathrm{Gd}^{3+}$ concentrations of AGulX has already allowed observation of its accumulation in kidneys 5 min after

\footnotetext{
* Correspondence to: Mario Dentamaro and Sophie Laurent, CMMI - Center for Microscopy and Molecular Imaging, Gosselies, Belgium. E-mail mario. dentamaro@gmail.com; sophie.laurent@umons.ac.be

a M. Dentamaro, L. Vander Elst, S. Montante, C. Burtea, R. N. Muller, S. Laurent Mons, Belgium

b M. Dentamaro, F. Lux, O. Tillement

Villeurbanne, France

C M. Dentamaro, L. Vander Elst, R. N. Muller, S. Laurent Gosselies, Belgium

d N. Dauguet Brussels, Belgium

e A. Moussaron

Villeurbanne, France
}

${ }^{1}$ The relaxivity is defined as the relaxation rate enhancement induced by $1 \mathrm{mmol}$ per litre of paramagnetic centre. 
administration, while in bladder and urine AGulX nanoparticles were detected 25 min post-injection (5).

Owing to the high $Z$-number of the gadolinium element $(Z=64)$, the nanoparticles also have a radiosensitizing effect for radiology used for cancer treatment. Multifunctional polysiloxane-based nanoparticles are thus also efficient as theranostic platforms combining imaging and therapy $(1,4,6-8)$. Radiation therapy studies performed on tumoral cells $(9,10)$ have shown an amplification of X-ray effects when the irradiation is performed in the presence of nanoparticles. This was also confirmed under different types of irradiation such as hadrontherapy experiments (11).

Tumour targeting is a real challenge in clinical research. AGuIX nanoparticles can be sufficiently large to prevent their extravasation from normal vessels of healthy tissues and small enough for passive accumulation within solid tumours by the EPR (enhanced permeation and retention) effect $(4,12)$. This effect is a result of the combination between an increased tumour blood vessel permeability and a decreased rate of clearance caused by the absence of functional lymphatic vessels in the tumour $(13,14)$. However, an active targeting is also possible by conjugating AGulX with a vector specific to cancer cell receptors.

Our research group has previously described the functionalization of AGulX nanoparticles with various ligands for the targeting of tumours. These markers have been grafted on free carboxylic functions of uncomplexed DOTA derivatives covalently coupled at the surface of nanoparticles (15). We have shown that grafted AGulX is for example able to target, with an high efficiency, tumours overexpressing $\alpha_{v} \beta_{3}$-integrins using cyclic RGD as a specific peptide (16), or extracellular melanin pigment, present in melanoma cancer environment, using quinoxaline derivatives (17). Otherwise, grafted AGulX has also been labelled with the fluorophore cyanine 5.5 (Cy5.5), which gives bimodality properties with potential diagnostic applications by MRI and optical imaging (16).

In the present study, we focused on grafted AGulX nanoparticles as a multimodal probe for apoptotic cell detection. Apoptosis is a programmed cell death process. It is considered as a vital component of various processes including normal cell turnover and also the proper development and regulation of the immune system (18). In contrast to necrosis, an uncontrolled and passive process of cell death, apoptosis is an active and genetically controlled process, which does not lead to an inflammatory process as caused in necrosis by the loss of membrane cell integrity (19). The aim of this targeting is the diagnosis of pathologies associated with an excessive or an insufficient triggering of apoptosis, such as atherosclerosis, ischemia, chronic inflammation, autoimmune disorders, transplant rejection, neurodegenerative disorders, acquired immuno-deficiency syndrome (AIDS) and diabetes mellitus $(20,21)$. Apoptosis is also associated with cancer. Indeed, cancer cells are characterized by the development of several anti-apoptotic mechanisms, which allow them to escape from their programmed death and contribute to their uncontrolled proliferation (22). Most processes in cancer therapy are based on the reactivation of cell death programs, such as apoptosis, on malignant cells (23). Radiotherapy is one of the most local treatments against solid tumours inducing cell apoptosis, but is limited by cell resistance and toxicity on peripheral healthy tissues. Therefore, targeting apoptosis represents a potential interest to observe the efficiency of a cancer treatment on tumours (24) and also to quantify the radiation-induced apoptosis on peripheral normal tissues after radiotherapy (25).

Apoptosis mechanisms can be classified into two energydependent pathways: the extrinsic or death receptor pathway and the intrinsic pathway or mitochondrial pathway (18). These two pathways lead to DNA fragmentation, degradation of cytoskeletal and nuclear proteins, crosslinking of proteins, formation of apoptotic bodies associated with cell membrane blebbing and externalization of phosphatidylserine phospholipid and of ligands for phagocytic cell receptors (Fig. 1).

TLVSSL (E3) peptide was identified by phage display technology as having a high affinity for phosphatidylserine, with a $K_{\mathrm{a}}$ of about $2.5 \times 10^{6} \mathrm{M}^{-1}$, evaluated by the ELISA method $(26,27)$. This peptide was grafted on AGuIX nanoparticles previously

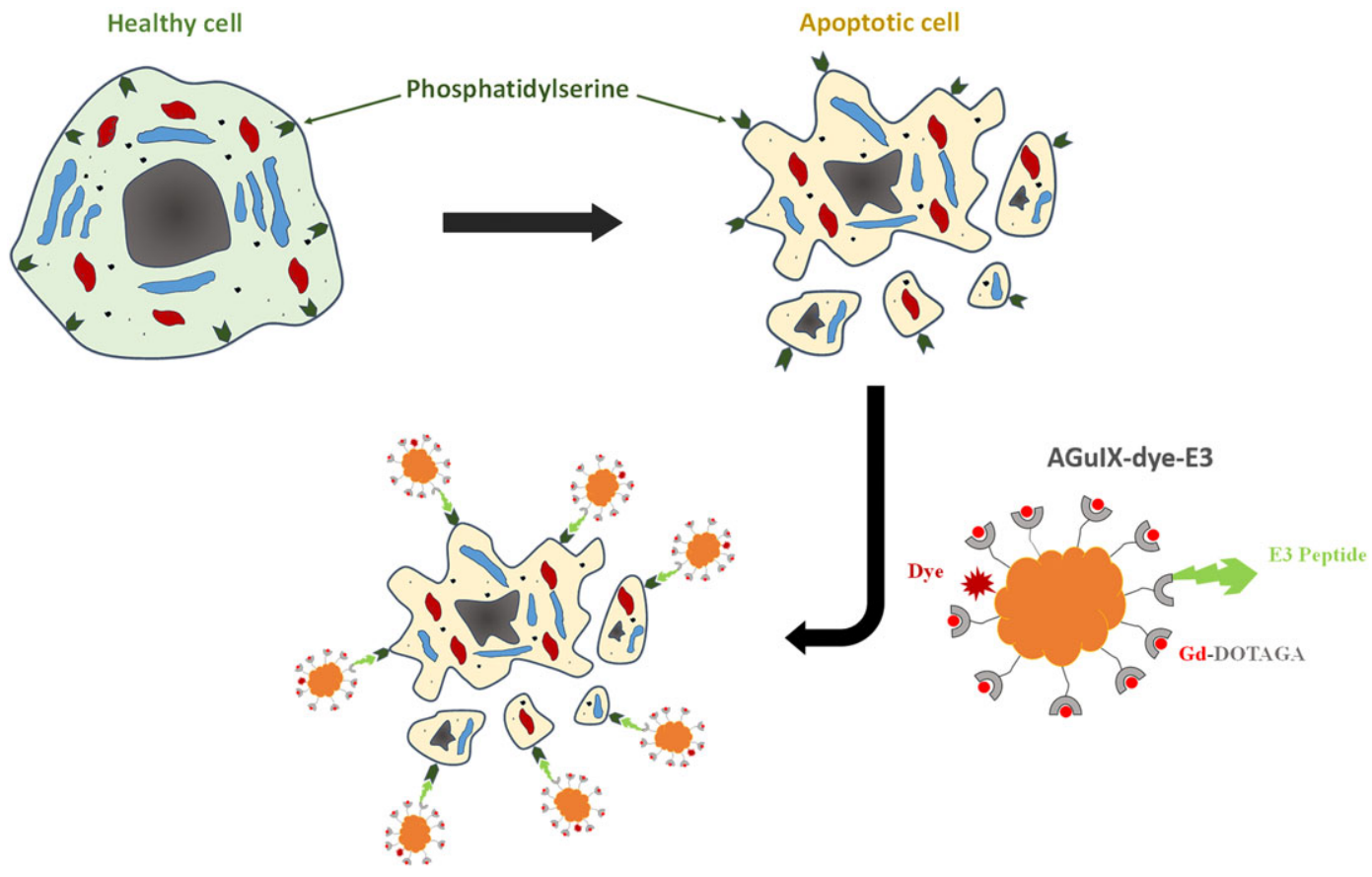

Figure 1. Schematic illustration of apoptotic cell formation, with the exposure of phosphatidylserine, and targeting by AGulX-dye-E3 nanoparticles. 
labelled with a fluorescent dye (Cy5.5 or rhodamine) to obtain an efficient bimodal probe to target apoptotic cells. Platforms were also grafted in the same conditions with the scramble SVSLLT peptide. Van Koninckxloo et al. (28) showed that the $K_{\mathrm{a}}$ of SVSLLT peptide is 28 times lower than the $K_{a}$ of TLVSSL peptide on a micellar model exposing phosphatidylserine.

This research has been focussed on the chemical synthesis and then the physico-chemical and biological characterizations of different types of grafted AGuIX nanoparticle. Nanoparticle size and relaxivity measurements were made to confirm the peptide grafting. Their efficiency as a new contrast agent to target apoptosis has been evaluated using an in vitro test on a lymphoblastic human T-cell line.

\section{MATERIALS AND METHODS}

\subsection{Synthesis}

\subsubsection{Materials and chemicals}

$\mathrm{N}$-(3-dimethylaminopropyl)-N'-ethylcarbodiimide hydrochloride (EDC, 98.0\%), core-shell nanoparticles (gadolinium oxide core and polysiloxane shell) were purchased from Nano-H (SaintQuentin-Fallavier, France). Gadolinium hydroxide hexahydrate $\left(\mathrm{GdCl}_{3} .6 \mathrm{H}_{2} \mathrm{O}, 99 \%\right)$, sodium hydroxide $(\mathrm{NaOH}, 99 \%)$, hydrochloric acid ( $\mathrm{HCl}, 36.5-38 \%)$, dimethylsulfoxide (DMSO, >99.5\%), dimethylformamide (DMF, >99.8\%) acetonitrile $\left(\mathrm{CH}_{3} \mathrm{CN}\right.$, $>99.9 \%)$, 4-(2-hydroxyethyl)piperazine-1-ethanesulfonic acid (HEPES, $>99.5 \%)$, sodium chloride $(\mathrm{NaCl},>99.5 \%)$, trifluoroacetic acid (TFA, >99\%), calcium chloride hexahydrate $\left(\mathrm{CaCl}_{2} \cdot 6 \mathrm{H}_{2} \mathrm{O}\right)$, Chelex ${ }^{\circledast} 100$ sodium form and rhodamine $B$ isothiocyanate (RITC, mixed isomers) were provided by Sigma Aldrich Chemical. Nitric acid $\left(\mathrm{HNO}_{3}, 67 \%\right)$ was purchased from Merck Belgium. Cyanine 5.5 (mono-reactive NHS ester) was provided by GE Healthcare. The TLVSSL peptide (abbreviated E3) was purchased from GeneCust Luxembourg. E3 scramble (SVSLLT), 8-amino-3,6dioxaotanoyl-7-TLVSSL (L-E3) and 8-amino-3,6-dioxaotanoyl-7SVSLLT (L-E3Scramble) were purchased from PolyPeptide Laboratories Group (Strasbourg, France). The anhydrous DOTAGA (1,4,7,10-tetraazacyclododecane-1-glutaric anhydride-4,7,10-triacetic acid) chelate was purchased from CheMatech (Dijon, France). The Vivaspin membranes (MWCO $=5 \mathrm{kDa}$ ) for tangential filtration of nanoparticles were purchased from Sartorius Stedim Biotech (France).

The synthesis of the core-shell nanoparticles (core gadolinium oxide and shell polysiloxane) in diethylene glycol (DEG) has been previously described by the present authors (29).

\subsubsection{Hydrolysis and complexation of anhydrous DOTAGA}

AGuIX nanoparticles contain Gd-DOTAGA ligands on their surface as described previously. In order to compare relaxometric properties of AGulX nanoparticles with a small $\mathrm{Gd}^{3+}$ complex, anhydrous DOTAGA was hydrolysed in basic aqueous solution (stirred overnight in $0.5 \mathrm{M} \mathrm{NaOH}$ solution at room temperature) and complexed adding $\mathrm{GdCl}_{3} \cdot 6 \mathrm{H}_{2} \mathrm{O}$ at $\mathrm{pH} 6$ to generate $\mathrm{Gd}$-DOTAGA. Uncomplexed $\mathrm{Gd}^{3+}$ ions were eliminated using Chelex ${ }^{\circledast} 100$ resin complex.

\subsubsection{Grafting of dye}

For the fluorescent labelling of AGuIX nanoparticles, two types of organic dye have been chosen, rhodamine B isothiocyanate or Cy5.5 NHS-ester. These fluorescent compounds were diluted in anhydrous DMSO (2.5 $\mathrm{mg} \mathrm{mL}^{-1}$ ) and added to an aqueous suspension at approximately $100 \mathrm{mM}$ of AGulX nanoparticles. For the two kinds of coupling reaction achieved on the amine function of the AGulX surface, the $\mathrm{pH}$ was in the range of 5-6. Cyanine 5.5 was added with a Cy $5.5 / \mathrm{Gd}^{3+}$ molar ratio of $1 / 700$, and rhodamine was added with an RITC/Gd ${ }^{3+}$ molar ratio of $1 / 100$.

RITC has been chosen to detect grafted AGulX nanoparticles and evaluate their specificity in in vitro experiments. Otherwise, due to a near-infrared fluorescence emission, Cy5.5 has been functionalized to characterize labelled-nanoparticles for further in vivo experiments.

\subsubsection{Grafting of peptides}

2.1.4.1. Peptide grafting on nanoparticles without fluorophore. First, two equivalents of EDC were added to an AGuIX suspension at $\mathrm{pH} 5$ to activate carboxylic functions on the nanoparticle surface. Peptides (E3, L-E3, E3Scramble, L-E3Scramble) were previously dissolved in a 50:50 DMF/Milli-Q water mixture (135 mM) and were added $30 \mathrm{~min}$ after EDC activation on the AGulX suspension. A ratio of 0.4 peptide $/ \mathrm{Gd}^{3+}$ at $\mathrm{pH} 7$ was used. The suspension was stirred overnight.

2.1.4.2. Peptide grafting on bimodal nanoparticles. Peptides were grafted after the dye labelling. Two equivalents of EDC were added first to unpurified dye-labelled AGuIX suspension to activate carboxylic functions on the surface. Peptides were previously dissolved in a 50:50 DMF/Milli-Q water mixture $(135 \mathrm{mM})$ and were added $30 \mathrm{~min}$ after EDC activation on dye-labelled AGulX suspension. A ratio of 0.4 peptide/Gd was used.

\subsubsection{AGuIX purification}

After the grafting, suspensions were purified by ultrafiltration with Vivaspin ${ }^{\circledast}$ (Sartorius, $5 \mathrm{kDa}$ polyethersulfone membrane) tubes, and finally freeze-dried.

\subsection{Nanoparticle characterization}

\subsubsection{Proton relaxation time analysis}

Longitudinal $\left(T_{1}\right)$ and transverse $\left(T_{2}\right)$ relaxation times were measured at $310 \mathrm{~K}$ using Bruker minispec (Bruker, Karlsruhe, Germany) (MQ20 (20 MHz, 0.47 T) and MQ60 (60 MHz, 1.4T)) nuclear magnetic resonance analysers. Measurements of longitudinal and transversal relaxation times at 300 and $500 \mathrm{MHz}$ were carried out using Avance 300 and Avance 500 spectrometers (Bruker, Ettlingen, Germany).

These values allow us to determine relaxation rates and relaxivities of the contrast agent:

$$
\begin{gathered}
R_{1,2}^{\text {obs }}=\frac{1}{T_{1,2}^{\text {obs }}} \\
r_{1,2}=\frac{R_{1,2}^{\text {obs }}-R_{1,2}^{\text {dia }}}{c}
\end{gathered}
$$

$R_{1,2}^{\text {obs }}$ is the observed longitudinal or transverse proton relaxation rate of a solution containing the contrast agent. $R_{1,2}^{\text {dia }}$ is the diamagnetic longitudinal or transverse proton relaxation of a water solution in the absence of contrast agent. The concentration of AGulX nanoparticles $(c)$ is expressed in $\mathrm{mmol} \mathrm{L}^{-1}$ of gadolinium. 


\subsubsection{Proton nuclear magnetic relaxation dispersion (NMRD) profiles}

NMRD profiles illustrate the evolution of longitudinal relaxation rate $R_{1}$ at different magnetic fields from $0.12 \mathrm{mT}$ to $1.2 \mathrm{~T}$. These NMRD profiles were recorded on a fast field cycling relaxometer (Stelar, Mede, Italy) at $37^{\circ} \mathrm{C}$.

\subsubsection{AGulX synthesis and purification}

A large excess of anhydrous DOTAGA ( $33 \mathrm{~g}$ ) was added to the core-shell particles in DEG ( $1 \mathrm{~L}$ at $\left.30 \mathrm{mM}\left[\mathrm{Gd}^{3+}\right]\right)$ for covalent grafting, with a ratio of two DOTAGA per $\mathrm{Gd}^{3+}$. The resulting mixture was stirred for $48 \mathrm{~h}$ at room temperature. The nanoparticles were then precipitated in acetone $(3 \mathrm{~L})$. Acetone was removed and the nanoparticles were washed two more times in acetone $(1.5 \mathrm{~L})$. The nanoparticles were then dispersed in water $(500 \mathrm{~mL})$. An aqueous solution of DTPA $120 \mathrm{mM}(500 \mathrm{~mL})$ was added to the nanoparticle dispersion. Finally, the remaining acetone was evaporated at $37^{\circ} \mathrm{C}$ overnight. Purification of the nanoparticles was performed by filtration through Vivaspin membranes $(\mathrm{MWCO}=5 \mathrm{kDa}$ ). The colloidal solution was introduced into $20 \mathrm{~mL}$ Vivaspin tubes, and centrifuged. This step was repeated several times, by filling the tube with water $\left(V_{i}\right)$ and centrifuging to a final volume $\left(V_{f}\right)$, until a purification rate (Pr) of 22000 was obtained. Pr was calculated according to

$$
\operatorname{Pr}=\frac{V_{\mathrm{i} 1} V_{\mathrm{i} 2} \ldots V_{\mathrm{ii}}}{V_{\mathrm{f} 1} V_{\mathrm{f} 2} \ldots V_{\mathrm{fi}}}
$$

Then, the solution was filtered through $0.2 \mathrm{~mm}$ syringe filters to remove the largest impurities. The solution was freeze-dried for storage, using a Christ Alpha 1-2 lyophilizator.

\subsubsection{Measurements of the gadolinium content in AGulX nanoparticles}

2.2.4.1. Developed protocol for AGuIX nanoparticles displaying non-complexed DOTA-like ligands. To $20 \mu \mathrm{L}$ of AGulX suspension in water, $80 \mu \mathrm{L}$ of $\mathrm{KOH}(2 \mathrm{M})$ was added. After $4 \mathrm{~h}, 200 \mu \mathrm{L}$ of nitric acid (67\%) and $100 \mu \mathrm{L}$ of $\mathrm{H}_{2} \mathrm{O}_{2}$ (30\%) were added and the solution was kept at room temperature for $48 \mathrm{~h}$. Longitudinal relaxation time $T_{1}$ was directly recorded in the acidic suspension at $37^{\circ}$ $\mathrm{C}$ and $60 \mathrm{MHz}$. The measured relaxation time allowed us to determinate a synthesis yield of $60 \%$ of gadolinium.

2.2.4.2. Developed protocol for functionalized AGuIX nanoparticles. To determine the concentration of nanoparticle suspension in equivalent of gadolinium ions, the suspension was diluted with one equivalent volume of nitric acid $67 \%$ and heated overnight at $75^{\circ} \mathrm{C}$.

These chemical processes allow the destruction of nanoparticles and the decomplexation of gadolinium ions from DOTA. The relaxation rate measured for the acidic suspension is directly proportional to the concentration of free gadolinium.

\subsubsection{Fluorescence measurements}

2.2.5.1. Measurement of non-complexed DOTA-like ligands by fluorescence titration. Fluorescence measurements were carried out using a Varian Cary Eclipse fluorescence spectrophotometer, in the resolved time mode. The parameters used were $395 \mathrm{~nm}$ excitation wavelength, which is a characteristic excitation for $\mathrm{Eu}^{3+}$ ions, excitation slit $10 \mathrm{~nm}$, emission slit $10 \mathrm{~nm}$, delay time $0.1 \mathrm{~ms}$ and gate time $5 \mathrm{~ms}$.

2.2.5.2. Fluorescence properties of labelled AGuIX. Fluorescence properties of labelled AGuIX nanoparticles were obtained by absorption and emission spectrum obtained with a LS55 fluorescence spectrometer (PerkinElmer, Waltham, MA, USA). The parameters used for Cy5.5-labelled AGulX were $679 \mathrm{~nm}$ excitation wavelength, excitation slit $4 \mathrm{~nm}$ and emission slit $5 \mathrm{~nm}$. The parameters used for RITC-labelled AGulX were $570 \mathrm{~nm}$ excitation wavelength, excitation slit $2.5 \mathrm{~nm}$ and emission slit $2.5 \mathrm{~nm}$.

\subsubsection{High performance liquid chromatography (HPLC)}

Gradient HPLC analysis was carried out using the Shimadzu Prominence series UFLC system equipped with a CBM-20A controller bus module, an LC-20 AD liquid chromatograph, a CTO20A column oven, an SPD-20A UV - visible detector at 295 and $350 \mathrm{~nm}$ and a RF-20A fluorescence detector. Analytical RP-HPLC was performed in A Jupiter C4 column $\left(150 \times 4.60 \mathrm{~mm}^{2}, 5 \mu \mathrm{m}\right.$, $300 \AA$, Phenomenex ${ }^{\circledast}$ with a gradient mobile phase $(95 \%$ Solvent $\mathrm{A} / 5 \%$ Solvent $B(A=$ Milli-Q water/TFA, 99.9/0.1 (v/v); $B=A C N /$ Milli-Q water/TFA, 90/9.9/0.1 (v/v/v)) at a flow rate of $1 \mathrm{~mL} \mathrm{~min}^{-1}$ (TFA, trifluoroacetic acid; CAN, acetonitrile). Samples were subsequently eluted with an enhancement of gradient from $5 \%$ to $90 \%$ of Solvent B (in Solvent A) over 30 min; the concentration of Solvent B was maintained over $10 \mathrm{~min}$ followed by a decrease to $5 \%$ over a period of $10 \mathrm{~min}$ to re-equilibrate the system. Before the analysis of each sample, a baseline was acquired under the same conditions by loading Milli-Q water into the injection loop. The column temperature was maintained at $25^{\circ} \mathrm{C}$. A volume of $20 \mu \mathrm{L}$ of samples was loaded at approximately $5 \mathrm{mM}$ Gd concentration at pH 7.4. The AGulX chromatogram acquired at $295 \mathrm{~nm}$, which corresponds to the maximum absorption of AGulX nanoparticles, presented a peak with a retention time of $10.2 \mathrm{~min}$. The purity was $90 \%$. The analysis of Cy5.5 systems was achieved with a fluorescence emission measured at $700 \mathrm{~nm}$ and an excitation at $675 \mathrm{~nm}$.

\subsubsection{Dynamic light scattering size measurement}

The hydrodynamic diameter and size distribution of nanoparticles was estimated using the dynamic light scattering (DLS) program of photon correlation spectroscopy (PCS). Data were collected at $20^{\circ} \mathrm{C}$ using a Zetasizer Zen 3600 particle size analyser with a $633 \mathrm{~nm}$ He-Ne laser from Malvern Instruments, UK.

For measurements, lyophilized particles were first dispersed in water for $1 \mathrm{~h}$ at room temperature, $\left[\mathrm{Gd}^{3+}\right]=100 \mathrm{mM}$ and $\mathrm{pH}=7.4$. Then particles were diluted to $\left[\mathrm{Gd}^{3+}\right]=2.5 \mathrm{mM}$ and measurements immediately made.

\subsubsection{Magnetic resonance imaging}

Acquisition of MRI images was performed at room temperature, on a 7T PharmaScan 70:16 imaging system (Bruker, Ettlingen, Germany). $T_{1}$-weighted images of contrast agent were obtained using a spin-echo sequence with the rapid acquisition with relaxation enhancement (RARE) method. Acquisition of $T_{2}$-weighted $\mathrm{MRI}$ images was conducted according to a turboRARE method. 


\subsection{In vitro characterizations}

\subsubsection{Apoptotic cells}

Affinity for apoptotic cells was evaluated on the Jurkat human T lymphocyte cell line. Cells were cultured in RPMI medium 1640 (Gibco ${ }^{\oplus}$, Life Technologies, Gent, Belgium) supplemented with $10 \%$ of foetal bovine serum (FBS, Gibco ${ }^{\oplus}$, Life Technologies) and $1 \%$ penicillin-streptomycin (Pen Strep, Gibco ${ }^{\circledR}$, Life Technologies). Apoptosis was induced by the incubation of Jurkat cells with camptothecin (MP Biomedicals, Brussels, Belgium). The apoptosis targeting efficiency of grafted AGulX nanoparticles was evaluated using fluorescence microscopy and relaxometry measurements on Jurkat cells treated with $2 \mu \mathrm{M}$ of camptothecin over $24 \mathrm{~h}$.

2.3.1.1. In vitro characterization of targeting efficiency. Treated and control cells were resuspended in fresh culture medium. After centrifugation ( $4500 \mathrm{rpm}, 15 \mathrm{~min}$ ), the apoptosis induction rate was evaluated using an annexin $\mathrm{V}$ apoptosis detection kit (FITC-annexin V, propidium iodide (PI), Sigma Aldrich Chemicals) on $5 \times 10^{5}$ cells at the concentration of $10^{6}$ cells $\mathrm{mL}^{-1}$ in $\mathrm{Ca}^{2+}$ buffer containing $20 \mu \mathrm{L}$ of $2 \mu \mathrm{g} \mathrm{mL}^{-1}$ Hoechst 33342 trihydrochloride (Life Technologies) to stain the DNA of cells. PI was used to stain the DNA of necrotic and late apoptotic state cells.

\subsubsection{Evaluation of apoptotic cells targeting efficiency by} fluorescence microscopy

Control and apoptotic cells were incubated with nanoparticles for $2 \mathrm{~h}$ at room temperature under mechanical stirring at a gadolinium concentration of $0.8 \mathrm{mmol} \mathrm{L}^{-1}$ in nanoparticles. Grafted and labelled AGuIX nanoparticles were added to $4 \times 10^{6}$ cells at the concentration of $2 \times 10^{6}$ cells $\mathrm{mL}^{-1}$. Subsequently, the cells were centrifuged ( $4500 \mathrm{rpm}, 15 \mathrm{~min}$ ) and rinsed three times with $2 \mathrm{~mL}$ of $\mathrm{Ca}^{2+}$ buffer $\left(2.5 \mathrm{mM} \mathrm{CaCl}_{2} ; 150 \mathrm{mM} \mathrm{NaCl} ; 10 \mathrm{mM}\right.$ HEPES; $\mathrm{pH}$ 7.4). Then, cell pellets were suspended in $25 \mu \mathrm{L}$ of mounting medium for fluorescence with DAPI (VECTASHIELD ${ }^{\circledR}$, Vector Laboratories, Labconsult, Brussels, Belgium). Cell pictures were taken with a DM2000 Leica microscope equipped with a DFC 425C camera (Leica Microsystems, Groot-Bijgaarden, Belgium). Experiments were performed in triplicate.

\subsubsection{Evaluation of apoptotic cells targeting efficiency by relaxometry and $M R I$}

Control and apoptotic cells were incubated with nanoparticles for $2 \mathrm{~h}$ at room temperature under mechanical stirring with $\mathrm{a}$ gadolinium concentration of $4 \mathrm{mmol} \mathrm{L}^{-1}$ in nanoparticles. Grafted and labelled AGuIX nanoparticles were added to $10^{7}$ cells at the concentration of $2 \times 10^{6}$ cells $\mathrm{mL}^{-1}$. Thereafter, the cells were centrifuged ( $4500 \mathrm{rpm}, 15 \mathrm{~min}$ ) and rinsed three times with $3 \mathrm{~mL}$ of $\mathrm{Ca}^{2+}$ buffer $(2.5 \mathrm{mM} \mathrm{CaCl} ; 150 \mathrm{mM} \mathrm{NaCl} ; 10 \mathrm{mM}$ HEPES; pH 7.4). Then, cell pellets were suspended in $80 \mu \mathrm{L}$ of gelatin (Sigma Aldrich, Diegem, Belgium) previously dissolved in $\mathrm{Ca}^{2+}$ buffer. Longitudinal relaxation times of suspended cell pellets were acquired with the MQ60 minispec instrument at $15^{\circ} \mathrm{C} . T_{1}$-weighted images and $T_{1}$ measurements of pellets were also obtained with a PharmaScan 7T MRI scanner.

\subsubsection{Flow cytometry}

The specificity of grafted AGuIX nanoparticles for apoptotic cells was also evaluated using a LSRFortessa flow cytometer (BD

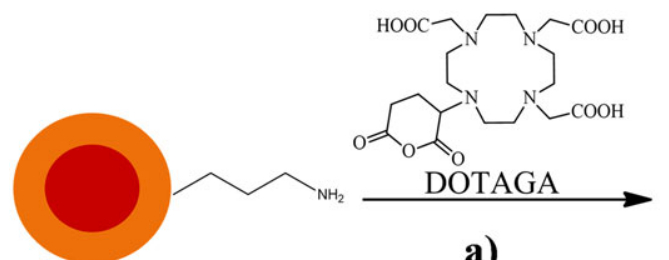

a)
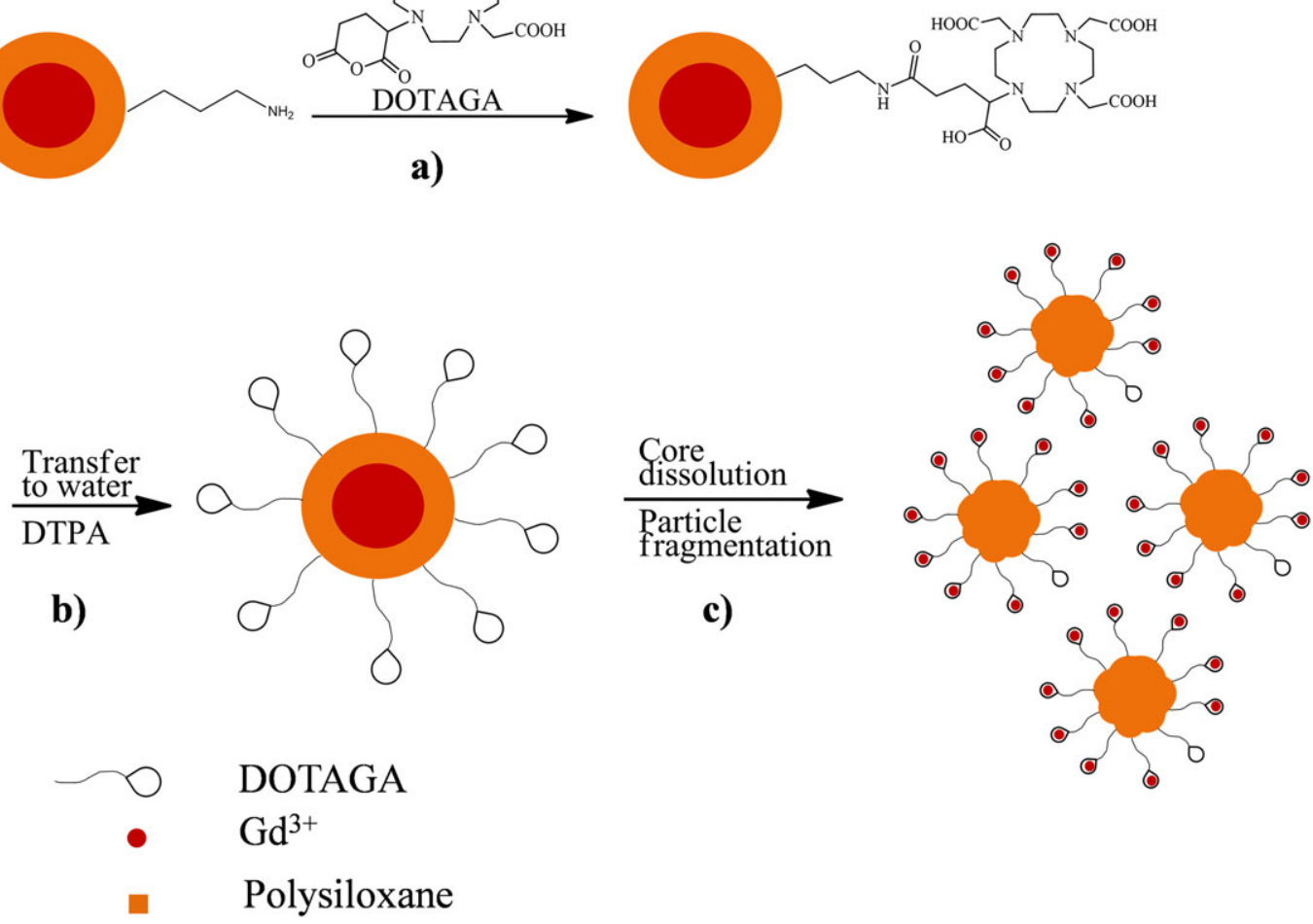

Figure 2. Preparation of AGulX: (a) DOTAGA grafting, (b) transfer to water and addition of DTPA and (c) core dissolution and polysiloxane fragmentation. 


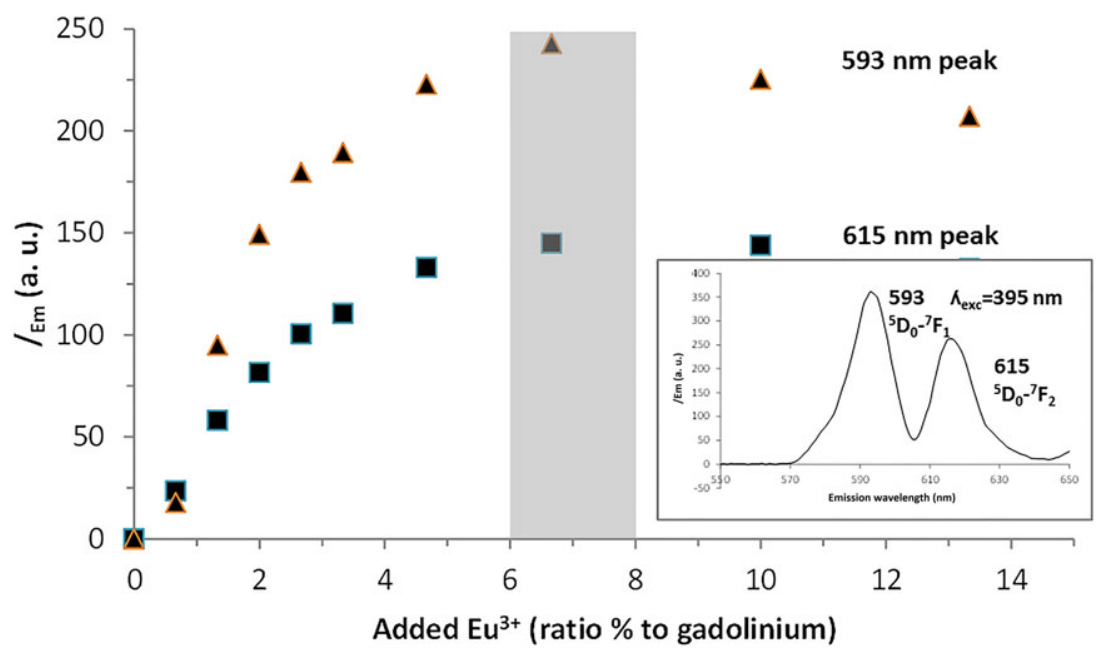

Figure 3. Quantification of the ratio of non-complexed DOTA-like ligands by time-resolved luminescence with a time delay of $0.2 \mathrm{~ms}$. The intensities of ${ }^{5} D_{0}-{ }^{7} F_{1}$ (squares) and ${ }^{5} D_{0}-{ }^{7} F_{2}$ (triangles) transition peaks are plotted as a function of increasing amounts of Eu ${ }^{3+}$.

Biosciences, Franklin Lakes, NJ, USA). Analyses were performed on Jurkat cells previously treated with camptothecin and incubated with grafted and labelled AGuIX. Before each experiment, cells $\left(3 \times 10^{5}\right.$ in $200 \mu \mathrm{L}$ of $\mathrm{Ca}^{2+}$ buffer) were stained with $10 \mu \mathrm{L}$ of 7-amino-actinomycin (7-AAD $0.05 \mathrm{mg} \mathrm{mL}^{-1}$, Life Technologies) and $5 \mu \mathrm{L}$ of FITC-annexin $\mathrm{V}\left(25 \mu \mathrm{g} \mathrm{mL}^{-1}, \mathrm{BD}\right.$ Pharmingen). 7AAD is known to target effectively the DNA of dead and late apoptotic state cells. Annexin V is a large protein known to target phosphatidylserine on cell membranes at the early stage of apoptosis. RITC-labelled AGuIX nanoparticles were detected using a yellow-green (561 nm) laser for excitation with a BP 582/15 nm filter for emission. Experiments were performed in triplicate.

\section{RESULTS AND DISCUSSION}

\subsection{Nanoparticle synthesis}

The gadolinium oxide core, the polysiloxane shell, with a ratio of 4:1 for Si:Gd, and the grafting of DOTAGA onto the amine functions of the core-shell particles, were prepared in diethylene glycol (DEG) according to our previously reported strategy $(4,30)$.

The DOTA-like ligands were grafted using anhydrous DOTAGA through amide bonds between amine functions on nanoparticles and glutaric anhydride on DOTAGA (Fig. 2(a)).

The particles were then transferred to water. The core dissolution leads to fragmentation of the polysiloxane shell into ultrasmall rigid platforms (USRPs) of polysiloxane, as previously demonstrated with DTPA and DOTA derivatives $(1,4)$. The resulting $\mathrm{Gd}^{3+}$ from the core dissolution was chelated by DOTA-like ligands. In order to eliminate some of the $\mathrm{Gd}^{3+}$ and to keep some non-complexed ligands on the surface, these USRPs were then treated with DTPA solution (Fig. 2(b), (c)). DTPA, Gd-DTPA, unreacted reagents and the smallest nanoparticles were then removed by tangential filtration using $5 \mathrm{kDa}$ cut-off membranes. After the purification, the USRPs, also called AGuIX nanoparticles, were freeze-dried for storage. They were dispersed again in water before use, and the hydrodynamic diameter obtained after dispersion is equal to the diameter before freeze-drying (about $1.8 \mathrm{~nm}$ ).

The quantification of the ratio of non-complexed DOTA-like ligands was determined by $\mathrm{Eu}^{3+}$ time-resolved luminescence.

\subsection{Measurement of non-complexed DOTA-like ligands by fluorescence titration}

To obtain the quantitative proportion of non-complexed DOTA-like ligands, time-resolved luminescence experiments were performed after addition of europium cations in a solution containing USRPs. It is possible to differentiate the free ligands from the complexed ones, since only the first are able to chelate additional europium cations. This chelation can be easily followed by the correlative change in the europium luminescence. Indeed, free europium cations have a luminescence almost completely quenched by the $\mathrm{OH}$ oscillators present in water, whereas the complexed $\mathrm{Eu}^{3+}$ are preserved from quenching by the protecting surrounding ligand. Several sets were prepared by addition of different amounts of europium cations to the nanoparticles, ranging from zero to one times the gadolinium content. That is, europium chloride $\left(\mathrm{EuCl}_{3}\right.$, $6 \mathrm{H}_{2} \mathrm{O}$ ) was dissolved in water, and added to the nanoparticle solutions. Because of the $\mathrm{H}^{+}$release during rare earth complexation, the $\mathrm{pH}$ of the solutions was adjusted to 6 , which is high enough for fast gadolinium complexation, but simultaneously low enough to prevent hydroxide formation. The mixtures were heated for $48 \mathrm{~h}$ at $80^{\circ} \mathrm{C}$. Luminescence measurements were made in water solutions containing $15 \mathrm{mM}$ of gadolinium. $\mathrm{Eu}^{3+}$ cations were excited at $395 \mathrm{~nm}$, which permits us to obtain two emission peaks: $5 D_{0}-7 F_{1}$ at $593 \mathrm{~nm}$ and $5 D_{0}-7 F_{2}$ at $615 \mathrm{~nm}$.

For small amounts of added $\mathrm{Eu}^{3+}$ ( $<6 \%$ per gadolinium), the intensity of both emission peaks increases with the amount of

Table 1. Hydrodynamic diameter study of synthesized AGuIX nanoparticles

\begin{tabular}{|lc|} 
& HD $(\mathrm{nm})$ \\
\hline AGulX & $2.7 \pm 0.7$ \\
AGulX-E3 & $4.0 \pm 1.2$ \\
AGulX-RITC & $4.5 \pm 2.1$ \\
AGulX-RITC-E3 & $5.1 \pm 1.9$ \\
AGulX-L-E3 & $3.8 \pm 1.4$ \\
AGulX-RITC-L-E3 & $3.9 \pm 1.3$ \\
\hline
\end{tabular}


Table 2. Relaxivity values, at $20 \mathrm{MHz}$ and $60 \mathrm{MHz}$, of AGulX nanoparticles at $2 \mathrm{mM}\left[\mathrm{Gd}^{3+}\right]$, measured 5 min after dilution

\begin{tabular}{|c|c|c|c|c|c|c|c|c|c|c|c|}
\hline & AGulX & $\begin{array}{c}\text { AGulX- } \\
\text { E3 }\end{array}$ & $\begin{array}{l}\text { AGulX- } \\
\text { E3SC }\end{array}$ & $\begin{array}{l}\text { AGulX- } \\
\text { L-E3 }\end{array}$ & $\begin{array}{l}\text { AGulX- } \\
\text { L-E3SC }\end{array}$ & $\begin{array}{c}\text { AGulX- } \\
\text { Cy5.5 }\end{array}$ & $\begin{array}{l}\text { AGulX- } \\
\text { Cy5.5-E3 }\end{array}$ & $\begin{array}{l}\text { AGulX- } \\
\text { RITC }\end{array}$ & $\begin{array}{l}\text { AGulX- } \\
\text { RITC-E3 }\end{array}$ & $\begin{array}{l}\text { AGulX- } \\
\text { RITC-E3Sc }\end{array}$ & $\begin{array}{l}\text { AGulX- } \\
\text { RITC-L-E3 }\end{array}$ \\
\hline $\begin{array}{l}r_{1}\left(\mathrm{~s}^{-1} \mathrm{mM}^{-1}\right) \\
\left(37^{\circ} \mathrm{C}, 20 \mathrm{MHz}\right)\end{array}$ & 7.8 & 12.7 & 13.0 & 18.2 & 18.4 & 13.0 & 13.1 & 12.9 & 16.1 & 14.1 & 17.7 \\
\hline $\begin{array}{l}r_{2}\left(\mathrm{~s}^{-1} \mathrm{mM}^{-1}\right) \\
\left(37^{\circ} \mathrm{C}, 20 \mathrm{MHz}\right)\end{array}$ & 8.7 & 14.7 & 14.6 & 20.8 & 21.1 & 13.8 & 14.0 & 13.9 & 17.4 & / & 20.7 \\
\hline$r_{2} / r_{1}(20 \mathrm{MHz})$ & 1.1 & 1.1 & 1.1 & 1.1 & 1.1 & 1.1 & 1.1 & 1.1 & 1.1 & / & 1.2 \\
\hline $\begin{array}{l}r_{1}\left(\mathrm{~s}^{-1} \mathrm{mM}^{-1}\right) \\
\left(37^{\circ} \mathrm{C}, 60 \mathrm{MHz}\right)\end{array}$ & 6.9 & 10.3 & 10.6 & 15.2 & 15.4 & 11.6 & 11.4 & 11.2 & 12.1 & 12.1 & 15.7 \\
\hline $\begin{array}{l}r_{2}\left(\mathrm{~s}^{-1} \mathrm{mM}^{-1}\right) \\
\left(37^{\circ} \mathrm{C}, 60 \mathrm{MHz}\right)\end{array}$ & 8.9 & 15.3 & 15.6 & 21.8 & 22.7 & 15.3 & 16.0 & 15.0 & 18.9 & 20.4 & 21.5 \\
\hline$r_{2} / r_{1}(60 \mathrm{MHz})$ & 1.3 & 1.5 & 1.5 & 1.4 & 1.5 & 1.3 & 1.4 & 1.3 & 1.6 & 1.7 & 1.4 \\
\hline
\end{tabular}

$\mathrm{Eu}^{3+}$, which evidences the formation of increasing quantities of luminescent $\mathrm{Eu}^{3+}$ chelates. For large amounts of added $\mathrm{Eu}^{3+}$ $(>8 \%)$, the luminescence intensity reached a plateau (Fig. 3), the additional $\mathrm{Eu}^{3+}$ remaining free (thus non-luminescent) in solution. Therefore we can evaluate the ratio of non-complexed DOTA-like ligands as $7 \% \pm 1 \%$ of the amount of gadolinium present in the particles.

\subsection{Dye and peptide grafting}

Peptide-grafted AGulX was synthesized by the formation of amide bonds between free carboxylic functions of AGuIX and $\mathrm{N}$-terminal functions of the peptide using the coupling agent EDC. AGuIX nanoparticles have approximately $10 \mathrm{Gd}^{3+}$ ions complexed on their surface. A grafting rate of 0.4 peptide/Gd has been chosen, corresponding to a ratio of 4 peptides per nanoparticle, which is an excess ratio considering that the platform has around one fixation site. To increase the peptide mobility, AGulX was also grafted with peptides bound to a linker through an amide bond with 8-amino-3,6-dioxaoctanoic acid. For dyelabelled nanoparticles, RITC or Cy5.5 was grafted on the amine function on the AGulX surface by thiourea bonds for RITC and by amide bonds for Cy5.5. Some of these particles were further grafted with peptides (AGulX-RITC-E3, AGulX-RITC-L-E3, AGulX-RITC-E3Sc, AGulX-RITC-L-E3Sc, AGulX or AGulX-Cy5.5).

\subsection{Grafted AGuIX physical characterizations}

DLS analyses performed on $10 \mathrm{mM}$ suspensions showed an increase of hydrodynamic diameter after the grafting of AGulX nanoparticles with RITC, the peptide or both (Table 1 and Fig. S1 in supporting information). AGulX labelled with Cy5.5 could not be analysed by DLS due to the high fluorescence absorbance at the wavelength of the laser source $(633 \mathrm{~nm})$.

The grafting of the peptide is thus confirmed by the enhancement of the hydrodynamic diameter measured with PCS. Moreover, an increase of nanoparticle size is also observed with HPLC through the increase of the retention time of AGulXCy5.5-E3 suspensions eluted into a column (Fig. S4 in supporting information). The UV-visible absorption detector was fixed at $295 \mathrm{~nm}$, a wavelength specific to each type of AGulX nanoparticle. Chromatograms showed different retention times: $10 \mathrm{~min}$ for AGuIX nanoparticles, $11 \mathrm{~min}$ for AGuIX-Cy5.5 and finally $12.5 \mathrm{~min}$ for AGulX-Cy5.5-E3. AGulX-Cy5.5-E3 nanoparticles were detected at the same time on both detectors (UV and fluorescence), which confirmed the functionalizations by Cy5.5 dye and by the peptide.

Measurements of relaxation rates give indications of the efficiency of these gadolinium-based MRI contrast agents. Longitudinal $\left(r_{1}\right)$ and transverse $\left(r_{2}\right)$ relaxivities (Table 2$)$ were measured. These relaxivities have been obtained by a measurement of relaxation times $5 \mathrm{~min}$ after the dilution of AGulX nanoparticles at $2 \mathrm{mM}\left[\mathrm{Gd}^{3+}\right]$ in HEPES buffer at $\mathrm{pH}$ 7.4.

These measurements indicate an enhancement of transverse and longitudinal relaxivities for AGulX nanoparticles after their grafting. NMRD profiles performed on $4 \mathrm{mM}$ suspensions, $10 \mathrm{~min}$ after their dilutions, showed a proton relaxation enhancement (PRE) at all magnetic fields (Fig. 4). Moreover, at clinical MRI frequencies $(6-130 \mathrm{MHz})$, the PRE for functionalized AGulX nanoparticles is quite high. This increase is usually explained by an increase in the rotational correlation time $\left(\tau_{R}\right)$ of the paramagnetic complex $(31,32)$. Table 3 shows the relaxivity values for AGuIX nanoparticles measured at 300 and $500 \mathrm{MHz}$ on more concentrated solutions $(>20 \mathrm{mM})$ to minimize degradation. As expected, the ratios $r_{2} / r_{1}$ of the grafted nanoparticles increase markedly, confirming the larger size after grafting.

The NMRD profiles of AGulX have been compared with the profile of a small $\mathrm{Gd}^{3+}$ complex, Gd-DOTAGA. As expected, the relaxivities of all AGulX particles are larger than those of Gd-DOTAGA over the whole frequency range. The fittings of the NMRD data were performed using the SolomonBloembergen-Morgan (SBM) model for the inner-sphere contribution and the Freed model for the outer-sphere contribution $(33,34)$. This classical analysis of the NMRD profile is known to be inadequate for the low field data of nanosized systems. In accordance with a well established approach (35-38), the data at magnetic fields lower than $3 \mathrm{MHz}$ were thus not included in the fittings. Table 4 summarizes the parameters obtained from the fittings of the profiles. For Gd-DOTAGA, the fitting was performed with the usual inner-sphere and outer-sphere contributions with the following parameters: $r=0.31 \mathrm{~nm} ; d=0.36 \mathrm{~nm} ; D=3.3 \times 10^{-9} \mathrm{~m}^{2} \mathrm{~s}^{-1}$ (39); $\tau_{M}=116 \mathrm{~ns}$ as determined by the analysis of the ${ }^{17} \mathrm{O}$ transverse relaxation rates as a function of the temperature (40) (Fig. $\mathrm{S} 7$ in supporting information); $q=1 ; \tau_{\mathrm{R}}=69$ $\pm 6.7 \mathrm{ps}, \tau_{\mathrm{SO}}=301 \pm 89 \mathrm{ps}$ and $\tau_{\mathrm{V}}=3.9 \pm 1.4 \mathrm{ps}$ at $310 \mathrm{~K}$. These values agree quite well with those reported by $\mathrm{F}$. Kielar et al. (38), except for the value of $\tau_{\mathrm{M}}$, which is slightly larger in our study. 

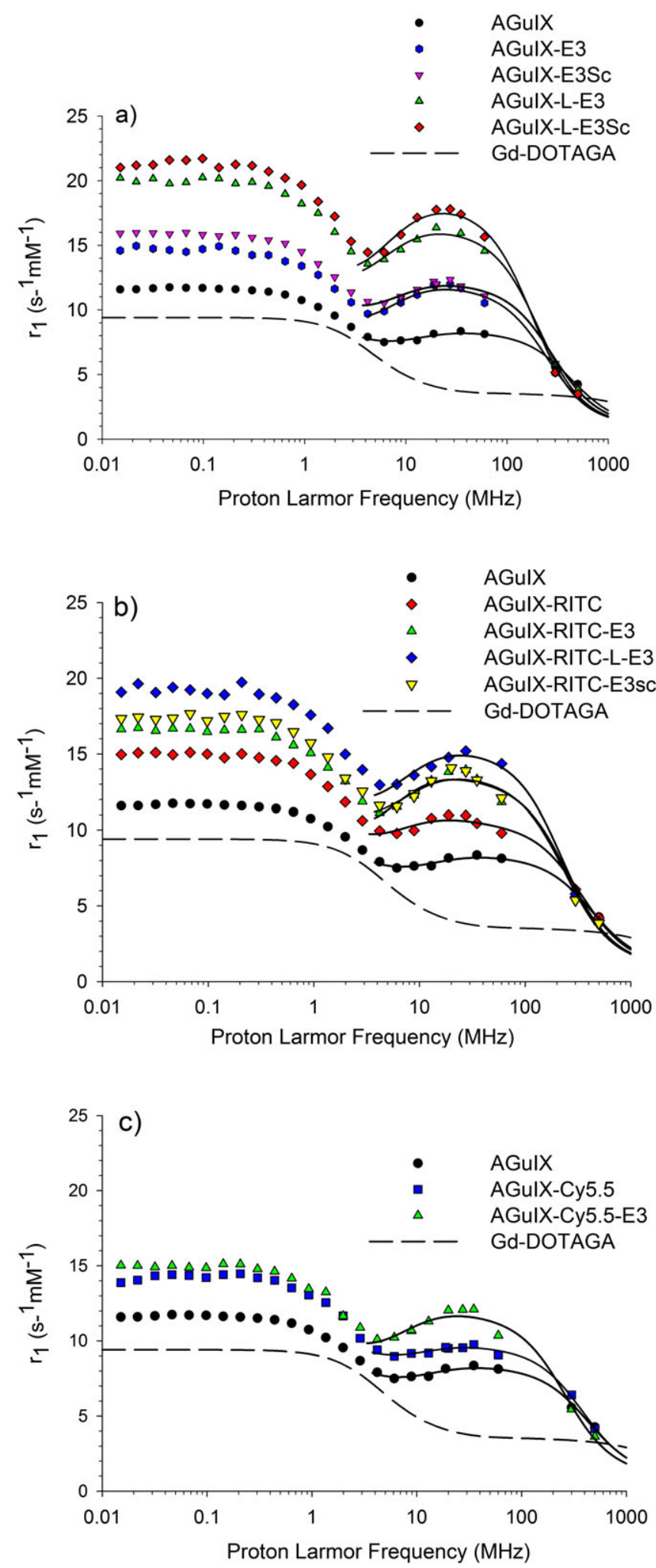

Figure 4. NMRD profiles of grafted AGulX nanoparticles suspended at $4 \mathrm{mM}\left[\mathrm{Gd}^{3+}\right]$ in water and measured $10 \mathrm{~min}$ after dilution and compared with non-grafted AGulX and Gd-DOTAGA. (a) NMRD profiles of each kind of non-labelled nanoparticle. (b) NMRD profiles of each kind of nanoparticle labelled with RITC. (c) NMRD profiles of each kind of synthesized AGuIX nanoparticle labelled with Cy5.5.
As shown by the data of Table 4, the water residence times obtained are markedly larger than for Gd-DOTAGA. This type of behaviour has already been reported by F. Kielar et al. (38) for paramagnetic lipid nanoparticles made of Gd-DOTAGA lipophilic derivatives inserted in liposomes. However, this increase of the water residence time is lower when a spacer is present (AGulX-L-E3, AGUIX-L-E3SC and AGuIX-RITC-L-E3). The graftings of both fluorophores result in similar NMRD profiles and have little influence on the tumbling but seem to lower slightly the water residence time as compared with AGulX. In contrast, the grafting of the peptides results in a marked increase of the rotational correlation time. In a second approach, the Lipari-Szabo model for the description of the local rotational dynamics was included in the theoretical fittings but the quality of the fittings was not markedly increased (results not shown).

$T_{1}$-weighted images (Fig. 5(a)) and $T_{2}$-weighted images (Fig. 5(b)) were obtained on $4 \mathrm{mM}\left[\mathrm{Gd}^{3+}\right]$ AGulX suspensions at 7.4 $\mathrm{T}$ at room temperature. They were acquired $30 \mathrm{~min}$ after the AGulX dilution. A clear positive contrast enhancement was observed for the paramagnetic AGulX, AGulX-E3 and AGulXCy5.5-E3 nanoparticles on $T_{1}$-weighted images.

At a magnetic field of $7 \mathrm{~T}(300 \mathrm{MHz})$, the longitudinal relaxivities of vectorized AGuIX and AGulX nanoparticles are in the same range. This explains the quite close brightness observed for the three types of AGuIX nanoparticle. However, at this high magnetic field, the transversal relaxivity $r_{2}$ of vectorized AGulX is markedly higher than the $r_{2}$ of nonvectorized nanoparticles (see Table 3); thereby, a more pronounced darkening can be observed on the $T_{2}$-weighted image of the vectorized AGulX.

\subsection{AGuIX stability}

As a result of the progressive degradation of the polysiloxane network, due to the hydrolysis of $\mathrm{Si}-\mathrm{O}-\mathrm{Si}$ bonds (41), the AGuIX nanoparticles are rapidly destabilized at low concentration and physiological $\mathrm{pH}$. The evolution of NMRD profile versus time of AGuIX displaying non-complexed DOTA-like ligands, performed with $4 \mathrm{mM}$ suspension (Fig. 6(a)), showed a global decrease of longitudinal relaxivity. Figure 6(b), (c) illustrates the AGulX degradation by the relaxivity percentage loss with time at fixed magnetic fields $(20 \mathrm{MHz}$ and $60 \mathrm{MHz})$. In aqueous-buffered suspension containing $2 \mathrm{mM}\left[\mathrm{Gd}^{3+}\right]$ at $\mathrm{pH} 7.4$, approximately $50 \%$ of the longitudinal relaxivity at $60 \mathrm{MHz}$ and $20 \mathrm{MHz}$ is lost after $70 \mathrm{~min}$, whereas the $r_{1,2}$ decrease of the $20 \mathrm{mM}$ solution is lower than $10 \%$. The kinetics of degradation is thus dependent on $\mathrm{Gd}^{3+}$ concentration in suspension (29).

Truillet et al.(42) published some studies on the aging of AGuIX nanoparticles. By HPLC-MS analysis, they characterized the degraded product of AGuIX nanoparticles as siloxane fragments with Gd-DOTA-like structures. This kind of degradation can be evoked to explain the relaxometric behaviour described earlier (Fig. 6(a)-(c)). Figure 6(a) shows the decrease of $r_{1}$ of AGulX nanoparticles. After $24 \mathrm{~h}$, the high field relaxivities are similar to the $r_{1}$ of Gd-DOTAGA, indicating that the rotational correlation times are close. The lower values of $r_{1}$ at low magnetic field after $24 \mathrm{~h}$ can be related to changes in the electronic relaxation rate of gadolinium of the degradation products, such as a decrease of the symmetry and/or 
Table 3. Relaxivity values, at 300 and $500 \mathrm{MHz}$, of AGulX nanoparticles suspended in water with highly concentrated conditions $(>20 \mathrm{mM} \mathrm{Gd})$

\begin{tabular}{|c|c|c|c|c|c|c|c|c|c|c|c|}
\hline & AGulX & $\begin{array}{c}\text { AGulX- } \\
\text { E3 }\end{array}$ & $\begin{array}{l}\text { AGulX- } \\
\text { E3SC }\end{array}$ & $\begin{array}{l}\text { AGulX- } \\
\text { L-E3 }\end{array}$ & $\begin{array}{l}\text { AGulX- } \\
\text { L-E3SC }\end{array}$ & $\begin{array}{l}\text { AGulX- } \\
\text { Cy5.5 }\end{array}$ & $\begin{array}{l}\text { AGulX- } \\
\text { Cy5.5-E3 }\end{array}$ & $\begin{array}{l}\text { AGulX- } \\
\text { RITC }\end{array}$ & $\begin{array}{l}\text { AGulX- } \\
\text { RITC-E3 }\end{array}$ & $\begin{array}{l}\text { AGulX- } \\
\text { RITC-E3SC }\end{array}$ & $\begin{array}{l}\text { AGulX- } \\
\text { RITC-L-E3 }\end{array}$ \\
\hline $\begin{array}{l}r_{1}\left(\mathrm{~s}^{-1} \mathrm{mM}^{-1}\right) \\
\left(37^{\circ} \mathrm{C}, 300 \mathrm{MHz}\right)\end{array}$ & 5.6 & 5.1 & 5.8 & 5.5 & 5.2 & 6.4 & 5.4 & 6.1 & 5.7 & 5.4 & 5.8 \\
\hline $\begin{array}{l}r_{2}\left(\mathrm{~s}^{-1} \mathrm{mM}^{-1}\right) \\
\left(37^{\circ} \mathrm{C}, 300 \mathrm{MHz}\right)\end{array}$ & 11.3 & 18.8 & 17.3 & 19.0 & 16.8 & 22.0 & 17.5 & 15.4 & 23.2 & 18.9 & 18.8 \\
\hline$r_{2} / r_{1}(300 \mathrm{MHz})$ & 2.0 & 3.7 & 3.0 & 3.4 & 3.2 & 3.4 & 3.2 & 2.5 & 4.1 & 3.5 & 3.2 \\
\hline $\begin{array}{l}r_{1}\left(\mathrm{~s}^{-1} \mathrm{mM}^{-1}\right) \\
\left(37^{\circ} \mathrm{C}, 500 \mathrm{MHz}\right)\end{array}$ & 4.3 & 5.1 & 4.0 & 3.7 & 3.5 & 4.8 & 3.6 & 4.2 & 4.0 & 3.9 & 3.8 \\
\hline $\begin{array}{l}r_{2}\left(\mathrm{~s}^{-1} \mathrm{mM}^{-1}\right) \\
\left(37^{\circ} \mathrm{C}, 500 \mathrm{MHz}\right)\end{array}$ & 10.0 & 21.1 & 17.3 & 20.5 & 16.8 & 21.0 & 19.0 & 15.0 & 22.5 & 21.7 & 18.4 \\
\hline$r_{2} / r_{1}(500 \mathrm{MHz})$ & 2.3 & 4.1 & 4.3 & 5.5 & 4.8 & 4.4 & 5.3 & 3.6 & 5.6 & 5.6 & 4.8 \\
\hline
\end{tabular}

Table 4. Parameter values obtained from the fittings of the NMRD profiles ${ }^{1}$

\begin{tabular}{|c|c|c|c|c|c|}
\hline & AGulX & AGulX-E3 & AGulX-E3SC & AGulX-L-E3 & AGulX-L-E3Sc \\
\hline$\tau_{\mathrm{R}}(\mathrm{ns})$ & $0.67 \pm 0.04$ & $1.36 \pm 0.05$ & $1.01 \pm 0.03$ & $1.34 \pm 0.04$ & $1.59 \pm 0.04$ \\
\hline$\tau_{M}(\mathrm{~ns})$ & $1880 \pm 53$ & $1410 \pm 29$ & $1220 \pm 26$ & $847 \pm 20$ & $764 \pm 16$ \\
\hline$\tau_{\mathrm{SO}}(\mathrm{ps})$ & $267 \pm 34$ & $237 \pm 56$ & $382 \pm 71$ & $450 \pm 72$ & $450 \pm 58$ \\
\hline \multirow[t]{2}{*}{$\tau_{\mathrm{V}}(\mathrm{ps})$} & $15 \pm 2$ & $31 \pm 7$ & $24 \pm 4$ & $33 \pm 2$ & $32 \pm 2$ \\
\hline & AGulX-RITC & AGulX-RITC-E3 & AGulX-RITC-E3sc & AGulX-RITC-L-E3 & AGulX-Cy5.5 \\
\hline$\tau_{\mathrm{R}}(\mathrm{ns})$ & $0.79 \pm 0.03$ & $1.11 \pm 0.04$ & $1.24 \pm 0.04$ & $1.20 \pm 0.04$ & $0.70 \pm 0.03$ \\
\hline$\tau_{M}(\mathrm{~ns})$ & $1360 \pm 35$ & $1060 \pm 24$ & $1090 \pm 24$ & $879 \pm 25$ & $1480 \pm 44$ \\
\hline$\tau_{\mathrm{SO}}(\mathrm{ps})$ & $352 \pm 92$ & $219 \pm 94$ & $392 \pm 80$ & $450 \pm 22$ & $450 \pm 50$ \\
\hline$\tau_{\mathrm{V}}(\mathrm{ps})$ & $28 \pm 7$ & $44 \pm 14$ & $28 \pm 6$ & $28 \pm 2$ & $15 \pm 2$ \\
\hline \multicolumn{6}{|c|}{ AGulX-Cy5.5-E3 } \\
\hline$\tau_{\mathrm{R}}(\mathrm{ns})$ & \multicolumn{5}{|l|}{$1.59 \pm 0.04$} \\
\hline$\tau_{M}(\mathrm{~ns})$ & \multicolumn{5}{|l|}{$764 \pm 16$} \\
\hline$\tau_{\mathrm{SO}}(\mathrm{ps})$ & \multicolumn{5}{|l|}{$450 \pm 58$} \\
\hline$\tau_{\vee}(p s)$ & \multicolumn{5}{|l|}{$32 \pm 2$} \\
\hline
\end{tabular}
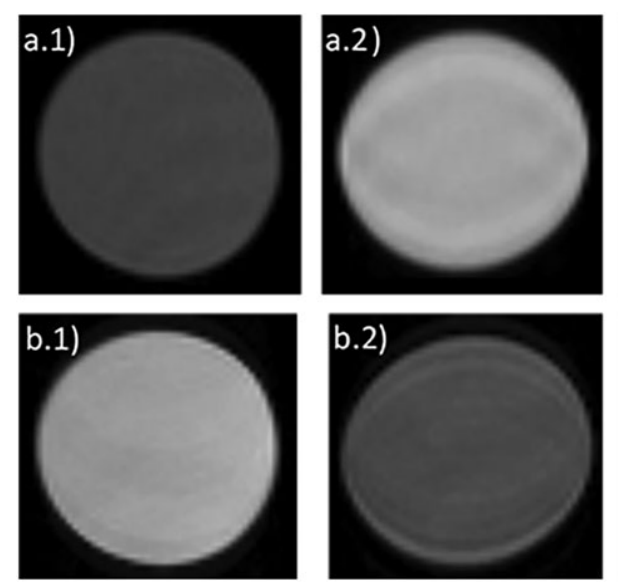
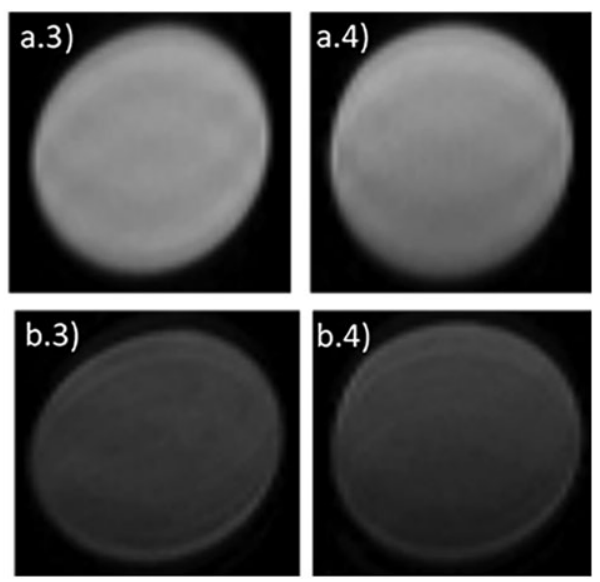

Figure 5. (a) $T_{1}$-weighted images of paramagnetic AGulX nanoparticles: (a.1) water; (a.2) AGulX NP; (a.3) AGulX-E3 NP; (a.4) AGulX-Cy5.5-E3 (TE = 9.1 ms, $T R=1300 \mathrm{~ms}$ ). (b) $T_{2}$-weighted images of paramagnetic AGulX nanoparticles: (b.1) water; (b.2) AGulX NP; (b.3) AGulX-E3 NP; (b.4) AGulX-Cy5.5-E3 (TE= $33.3 \mathrm{~ms}, T R=2500 \mathrm{~ms})$. 
a)

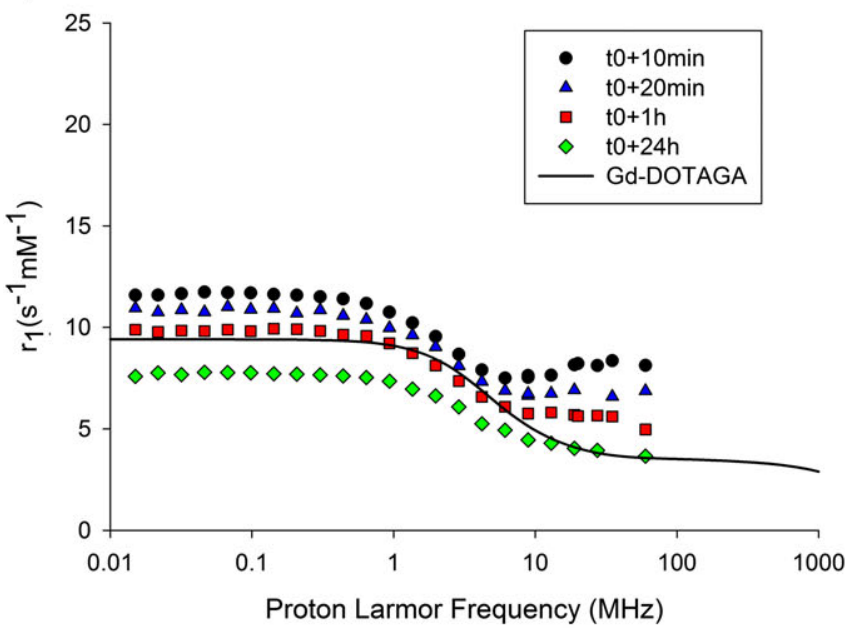

b)

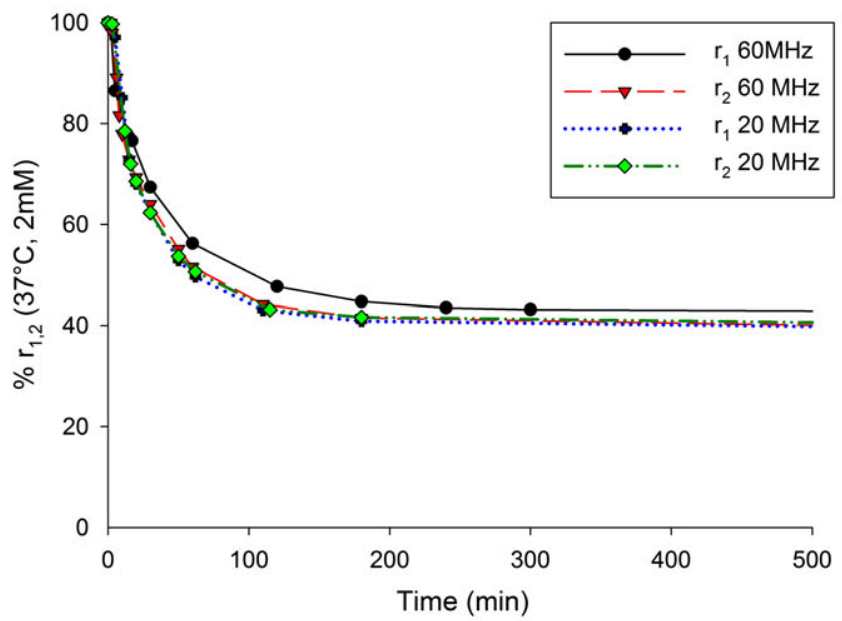

c)

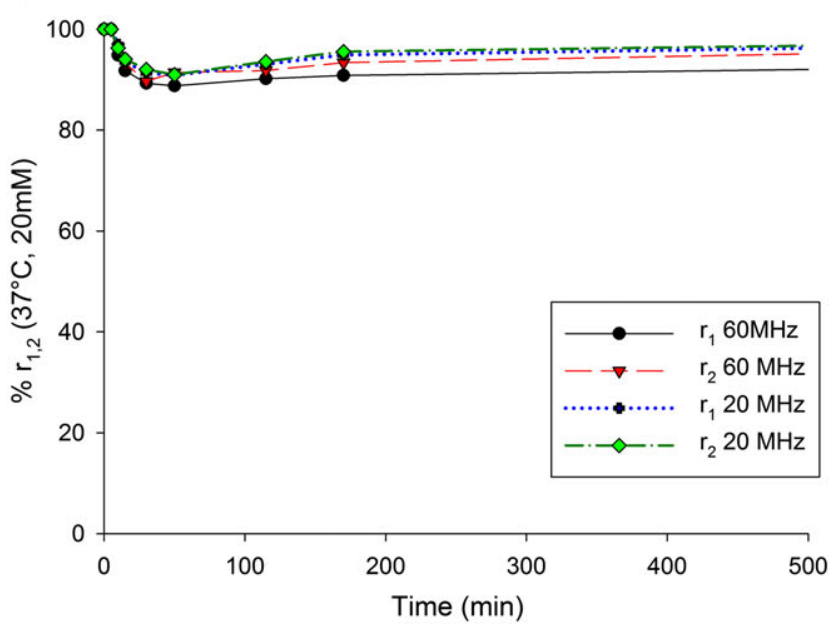

Figure 6. (a) Evolution of NMRD profiles of AGulX nanoparticles suspended in water at $4 \mathrm{mM}\left[\mathrm{Gd}^{3+}\right]$. (b) Evolution of the percentage loss of AGulX relaxivities at fixed magnetic fields in a $\mathrm{Ca}^{2+}$ buffer suspension at $2 \mathrm{mM}\left[\mathrm{Gd}^{3+}\right]$ and $\mathrm{pH} 7.4$. (c) Evolution of the percentage loss of AGulX relaxivities at fixed magnetic fields in a $\mathrm{Ca}^{2+}$ buffer suspension of $20 \mathrm{mM}\left[\mathrm{Gd}^{3+}\right]$ and $\mathrm{pH}$ 7.4.

the rigidity of these compounds as compared with GdDOTAGA.

These analyses performed on grafted AGuIX nanoparticles showed an AGulX stabilization induced by their grafting. Indeed, the degradation kinetics is slower, with a loss of $50 \%$ of $r_{1}$ reached after approximately $300 \mathrm{~min}$ (Fig. 7), as compared with $70 \mathrm{~min}$ for AGulX nanoparticles. 


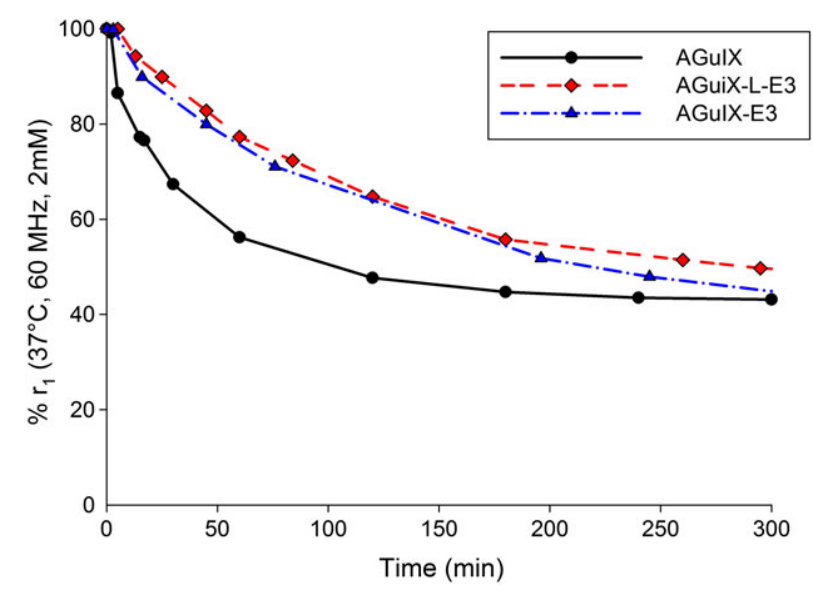

Figure 7. Evolution of the percentage loss of $r_{1}$ at $60 \mathrm{MHz}$ and $37^{\circ} \mathrm{C}$ of AGulX, AGuIX-E3 and AGulX-L-E3 in $\mathrm{Ca}^{2+}$ buffer at a concentration of $2 \mathrm{mM}\left[\mathrm{Gd}^{3+}\right]$.

\subsection{Fluorescence properties of labelled AGuIX}

For further in vivo applications by optical imaging it is necessary to use a fluorophore with a high tissue penetration of absorbed and emitted photons (43). This can be reached using NIR (700$1000 \mathrm{~nm}$ ) wavelengths in biomedical imaging. The organic fluorophore Cy5.5 has been chosen for its absorption and its fluorescence emission in the near infrared range. Cy5.5 was added at an initial ratio of $1 / 700 \mathrm{Gd}$ to obtain AGulX nanoparticles. The dye functionalization was confirmed by the maximum intensity of absorption at $676 \mathrm{~nm}$ and a maximum intensity of emission at $690 \mathrm{~nm}$ for AGulX-Cy5.5 and AGulX-Cy5.5-E3 (see supporting information).

The rhodamine fluorophore was grafted with an initial ratio of $1 \mathrm{RITC} / 100 \mathrm{Gd}$. After the labelled-platform grafting, the obtained RITC/Gd ratio was estimated by fluorescence spectroscopy using a calibration curve performed with RITC solutions. This ratio was evaluated at $0.006 \mathrm{RITC} / \mathrm{Gd}$.

\subsection{Non-covalent interaction study}

Human serum albumin (HSA) is a large protein known to constitute $4.5 \%$ of human plasma (44). Non-specific interactions between HSA and contrast agents will induce an extension of their blood half-life (45), increasing the time available to reach the specific target. A non-covalent binding should influence the PRE, with a change of the 'hump' between 9 and $60 \mathrm{MHz}$ (Fig. S5 in supporting information) and could modify the rate of degradation of the nanoparticles (46). The similarity of the profiles confirmed the absence of interaction between blood plasma protein HSA and AGuIX nanoparticles with and without peptide. (a)

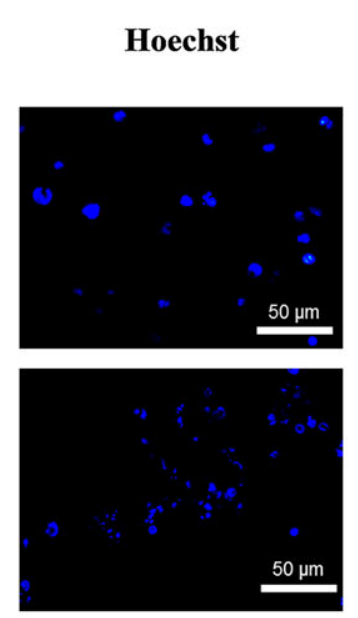

PI

(staining of dead and late apoptotic state cells)
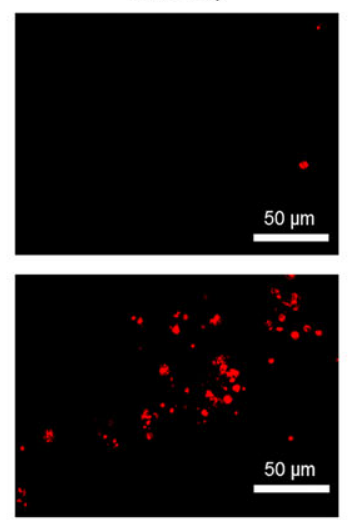

$50 \mu \mathrm{m}$
Annexin V-FITC

(staining of early apoptotic cells)
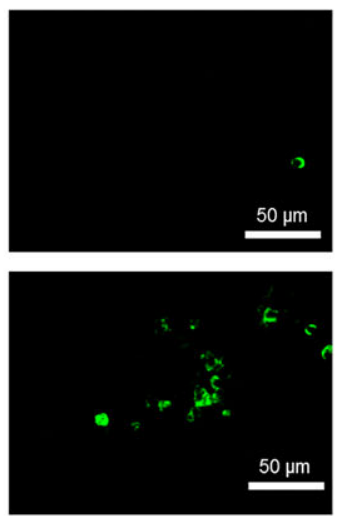

AGuIX-RITC-E3Sc
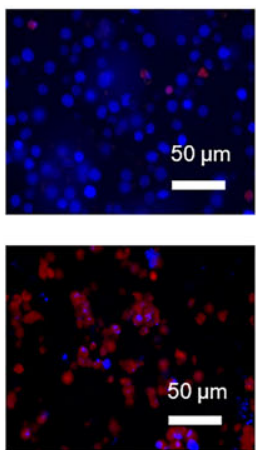

Merge
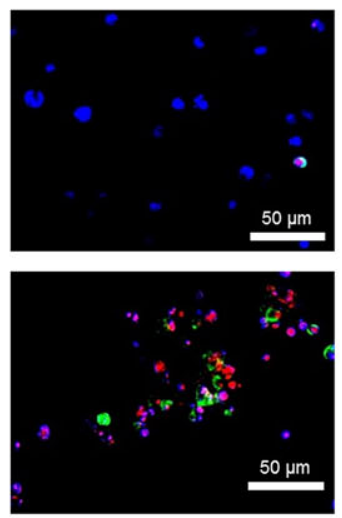

AGuIX-RITC-LE3Sc
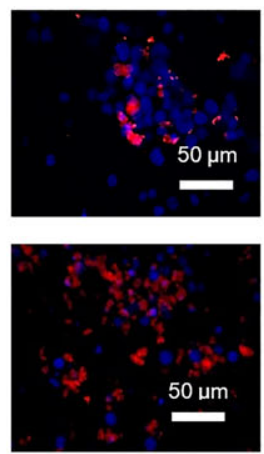
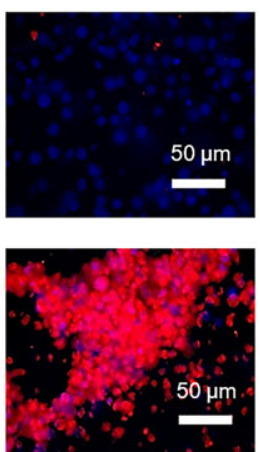

Figure 8. (a) Fluorescence microscopy of control cells and cells treated with $2 \mu \mathrm{M}$ camptothecin for $24 \mathrm{~h}$. Both cultures were stained with Hoechst, PI and annexin V-FITC. (b) Fluorescence microscopy merged images of control cells and cells treated with $2 \mu \mathrm{M}$ camptothecin for $24 \mathrm{~h}$ incubated with labelled AGulX-NP ( $800 \mu \mathrm{M}$ for $1 \mathrm{~h} 30 \mathrm{~min}$ ). 

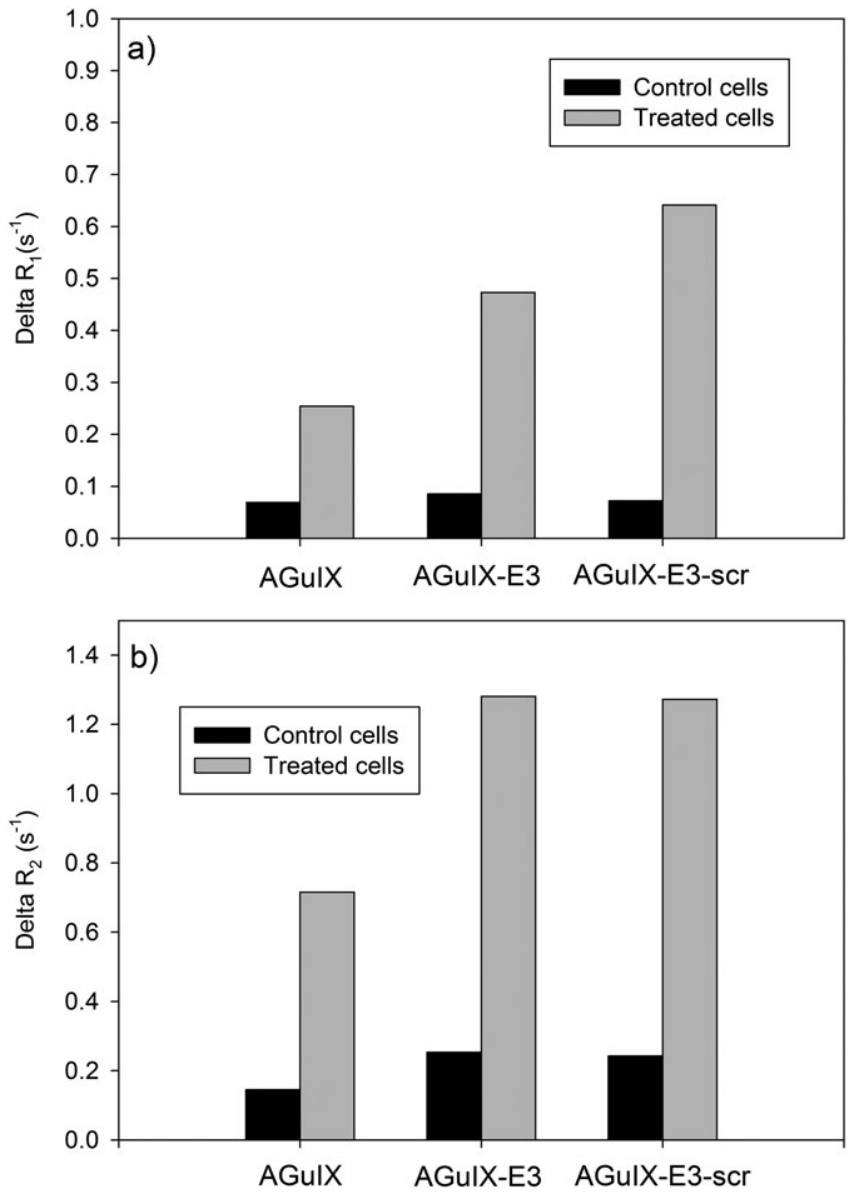

Figure 9. $\Delta R_{1}$ (a) and $\Delta R_{2}$ (b) of $10^{7} \mathrm{AGulX}$-incubated cells suspended in $80 \mu \mathrm{L}$ of gelatin at $15^{\circ} \mathrm{C}$ and $60 \mathrm{MHz}$. $\Delta R_{1,2}$ are defined as the differences between relaxation rates of AGulX-incubated cells and relaxation rates of non-incubated cells.

\begin{tabular}{|c|c|c|c|c|c|c|c|}
\hline & \multicolumn{4}{|c|}{ Control cells } & \multicolumn{3}{|c|}{ Treated-cells } \\
\hline & No NP & $A G U L X$ & $A G U L X-E 3$ & $A G U L X-E 3 S C$ & AGUIX & $A G U L X-E 3$ & $A G U L X-E 3 S C$ \\
\hline $\boldsymbol{R}_{1}\left(s^{-1}\right)$ & 0.326 & 0.353 & 0.375 & 0.352 & 0.408 & 0.475 & 0.563 \\
\hline
\end{tabular}

Figure 10. $7 \mathrm{~T} \mathrm{MRI} T_{1}$-weighted images and relaxation rates of $10^{7}$ incubated cell pellets suspended in $80 \mu \mathrm{L}$ of gelatin (RARE imaging protocol, $T R=440 \mathrm{~ms}, T E=9.1 \mathrm{~ms})$.

\subsection{In vitro characterization of targeting efficiency}

In order to confirm the specificity of grafted AGulX nanoparticles, they were tested in presence of apoptotic cells. The apoptosis targeting efficiency of grafted AGulX nanoparticles was first evaluated using fluorescence microscopy on Jurkat cells treated with $2 \mu \mathrm{M}$ of camptothecin over $24 \mathrm{~h}$. PI was used to stain the DNA of necrotic and late apoptotic state cells. Figure 8(a) illustrates that, after treatment, a large proportion of cells were in an early apoptotic state, but also in late apoptotic and necrotic states. In fact, both conditions overexpose phosphatidylserine on the cell surface. Double-stained cells were also observed (late apoptosis) (see supporting information).
In the presence of RITC-labelled nanoparticles (Fig. 8(b)), treated cells were effectively stained by vectorized nanoparticles. However the specificity of AGuIX-(L)-E3 cannot be confirmed, due to the higher targeting efficiency by E3 scramble-AGulX nanoparticles. Targeting of treated cells by vectorized AGulX was also confirmed by relaxometry $\left(60 \mathrm{MHz}, 15^{\circ} \mathrm{C}\right)$ (Fig. 9) and MRI study of incubated pellets, for which $R_{1}$ is 1.9 times higher when AGulX-E3 is incubated and 2.2 times higher when AGulX-E3SC is present as compared with AGulX-treated cells. For control cells, a slight increase ( $15 \%$ of maximum) of $R_{1}$ can be related to the presence of necrotic or late apoptotic cells in the culture. Similarly, a larger increase of $R_{2}$ is observed when 


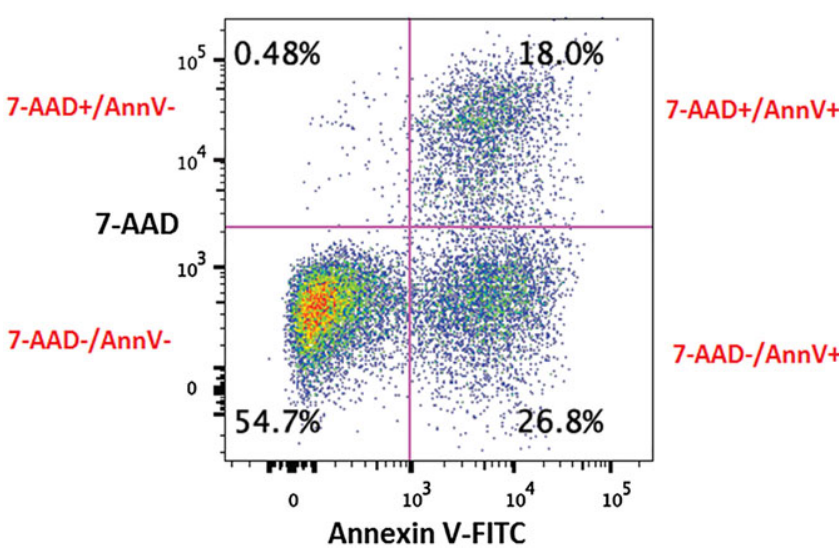

Figure 11. FACS diagram describing fluorescence intensity signal of each detected cell under annexin V-FITC and 7-AAD emission values in one sample.

AGuIX nanoparticles are grafted with the peptides. Longitudinal relaxation rates and the contrast in $T_{1}$-weighted images at $7 \mathrm{~T}$ confirmed that treated cells seem to be better targeted by AGulX grafted with E3 scramble (Fig. 10).

\subsection{Flow cytometry (FACS)}

\subsubsection{Cells in early state of apoptosis}

The FACS experiment allows discrimination of cells through their staining and their morphological conditions. Indeed the proportion in each cell state is easily recognized, making possible the analysis of targeting level for each single state of cells by labelled AGulX nanoparticles. A first experiment was performed to determine the best treatment to generate a high proportion of Jurkat cells in the early state of apoptosis, described as '7-AAD ${ }^{-} / \mathrm{AnnV}^{+1}$, unstained by 7-AAD and stained by annexin V-FITC. The Jurkat cell treatment with $5 \mu \mathrm{M}$ of camptothecin for $2 \mathrm{~h}$ was chosen. The average proportion in each cell staining is described in Table 5. A FACS diagram (Fig. 11) illustrated each cell population according to its staining.

A cell treatment with the same conditions as were used in microscopy and relaxometry experiments $(2 \mu \mathrm{M}$ for $24 \mathrm{~h})$ generates a higher proportion of Jurkat cells in the $7-\mathrm{AAD}^{+} / \mathrm{AnnV}^{+}$state (necrotic and late apoptotic cells) (see supporting information).

\subsubsection{Analysis of the specific apoptotic cells targeted by labelled} AGUIX

The FACS experiment was used to evaluate the specificity of labelled and vectorized AGuIX for apoptotic cells. Cells were first treated with camptothecin at $5 \mu \mathrm{M}$ for $2 \mathrm{~h}$ and incubated with nanoparticles. For this experiment, the population in 7-AAD ${ }^{-}$/ $\mathrm{AnnV}^{+}$stained cells was $14.05 \pm 1.28 \%$ and that of $7-\mathrm{AAD}^{+} / \mathrm{AnnV}^{+}$

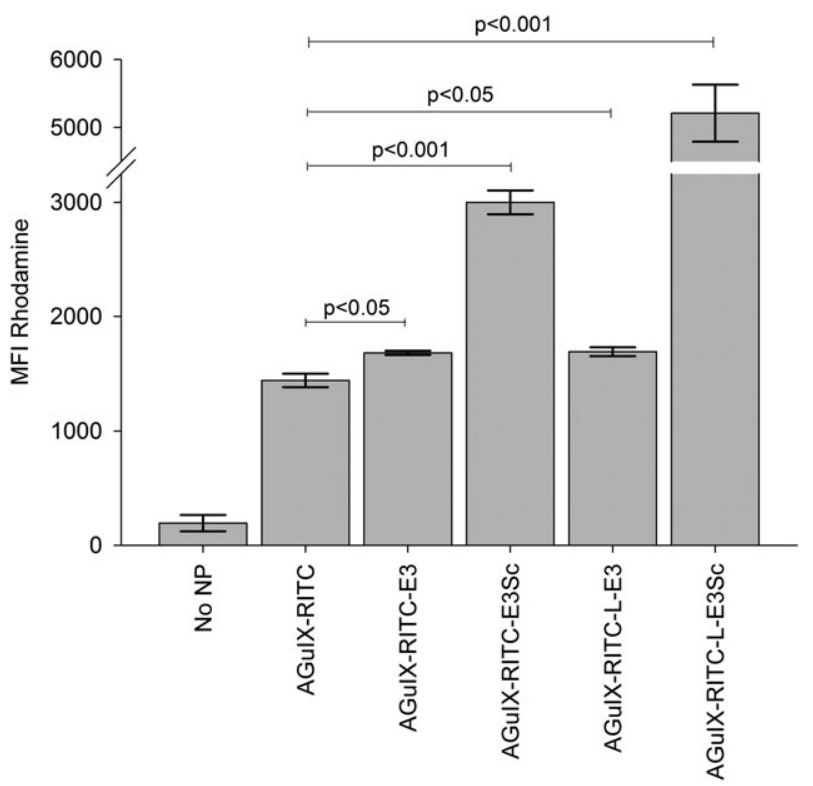

Figure 12. Fluorescence intensity median of rhodamine for early apoptotic cells in each incubated cell sample with RITC-labelled AGuIX.

was $33.17 \pm 2.15 \%$. The fluorescence intensity median in rhodamine for each cell population was measured (Fig. 12).

These experiments have been carried out considering an average of fluorescence medians measured for each sample. They show that on early apoptotic cells the measured fluorescence for grafted AGulX is significantly $(p<0.05)$ higher than the fluorescence observed for non-grafted AGuIX nanoparticles. They show also that the fluorescence of AGuIX grafted with E3 scramble peptide is larger than that of AGulX grafted with E3 peptide when the targeting of early apoptotic cells is considered. They also show the better targeting efficiency when a spacer is introduced between the nanoparticle and the E3 scramble peptide.

However, these analyses have been made on a cell sample where the apoptotic cells are concomitantly targeted by annexin V-FITC and the peptide-functionalized nanoparticles, leading to a possible competitive phenomenon.

\section{CONCLUSION}

Grafting of peptides has been confirmed by chemical and biological characterizations. Indeed, a general enhancement of relaxivity was observed after the AGulX functionalization, the nanoparticle size increased and the targeting of Jurkat apoptotic cells was confirmed by fluorescence microscopy, relaxivity and flow cytometry analysis. However, the in vitro tests performed on our cells seemed to highlight a better targeting efficiency of AGulX grafted with E3 scramble than E3. This could be explained by a possible modification of the spatial configuration of

Table 5. The average percentage of each kind of stained cells measured by flow cytometry in three cell samples

\begin{tabular}{|c|c|c|c|c|}
\hline Treatment & $\begin{array}{l}\% 7-\mathrm{AAD}^{+} / \mathrm{AnnV}^{-} \\
\text {Fragmented cells }\end{array}$ & $\begin{array}{c}\% 7-\mathrm{AAD}^{+} / \mathrm{AnnV}^{+} \text {Necrotic and late } \\
\text { apoptotic cells }\end{array}$ & $\begin{array}{l}\% \text { 7-AAD }{ }^{-} / \mathrm{AnnV}^{+} \text {Early } \\
\text { apoptotic cells }\end{array}$ & $\begin{array}{l}\% \text { 7-AAD }{ }^{-} / \mathrm{AnnV}^{-} \\
\text {Unstained cells }\end{array}$ \\
\hline $\begin{array}{l}\text { Camptothecin } \\
2 \mathrm{~h} 5 \mu \mathrm{M}\end{array}$ & $1.1 \pm 0.9$ & $18.1 \pm 0.2$ & $25.7 \pm 1.5$ & $54.9 \pm 0.4$ \\
\hline
\end{tabular}


peptides after their grafting on AGuIX nanoparticles, which could have modified their affinity for the target. In perspective, 3D modelling of spatial configurations of AGulX-E3 and AGulXE3Sc considering their interaction with phosphatidylserine should be performed.

\section{Acknowledgements}

This work was performed with the financial support of the Fonds National pour la Recherche Scientifique (F.R.S.-FNRS), FEDER, the Walloon Region, the COST Action TD1004 'Theranostics imaging and therapy: an action to develop novel nanosized systems for imaging-guided drug delivery', the Centre for Microscopy and Molecular Imaging (CMMI), supported by the European Regional Development Fund of the Walloon Region, and the ARC and UIAP programs. We also wish to thank Marie Plissonneau, Corinne Piérart, Fabien Rossetti, Fabian Rouffiange and Mathieu Roch for their contributions. We would also like to express our gratitude to French program ANR-12-RPIB-0010 Multimage for funding.

\section{REFERENCES}

1. Mignot A, Truillet $C$, Lux F, Sancey $L$, Louis $C$, Denat $F$, Boschetti $F$, Bocher L, Gloter A, Stéphan O, Antoine R, Dugourd P, Luneau D, Novitchi G, Figueiredo LC, De Morais PC, Bonneviot L, Albela B, Ribot F, Van Lokeren L, Déchamps-Olivier I, Chuburu F, Lemercier G, Villiers C, Marche PN, Le Duc G, Roux S, Tillement O, Perriat P. A top-down synthesis route to ultrasmall multifunctional Gd-based silica nanoparticles for theranostic applications. Chemistry 2013; 19: 6122-6136

2. Sancey L, Lux F, Kotb $S$, Roux $S$, Dufort $S$, Bianchi $A$, Crémillieux $Y$, Fries $P$, Coll J-L, Rodriguez-Lafrasse $C$, Janier $M$, Dutreix $M$, BarberiHeyob M, Boschetti F, Denat F, Louis C, Porcel E, Lacombe S, Le Duc G, Deutsch E, Perfettini J-L, Detappe A, Verry C, Berbeco R, Butterworth KT, McMahon SJ, Prise KM, Perriat $\mathrm{P}$, Tillement $\mathrm{O}$. The use of theranostic gadolinium-based nanoprobes to improve radiotherapy efficacy. Br J Radiol 2014; 87(1041: 20140134).

3. Bechet $D$, Auger $F$, Couleaud P, Marty E, Ravasi L, Durieux N, Bonnet $C$, Plénat $F$, Frochot $C$, Mordon S, Tillement $O$, Vanderesse R, Lux F, Perriat $P$, Guillemin F, Barberi-Heyob M. Multifunctional ultrasmall nanoplatforms for vascular-targeted interstitial photodynamic therapy of brain tumors guided by real-time MRI. Nanomedicine Nanotechnol Biol Med 2015; 11(3): 657-670.

4. Lux F, Mignot A, Mowat $P$, Louis C, Dufort $S$, Bernhard C, Denat F, Boschetti $F$, Brunet $C$, Antoine $R$, Dugourd $P$, Laurent $S$, Vander Elst L, Muller RN, Sancey L, Josserand V, Coll J-L, Stupar V, Barbier E, Rémy C, Broisat A, Ghezzi C, Le Duc G, Roux S, Perriat P, Tillement O. Ultrasmall rigid particles as multimodal probes for medical applications. Angew Chem Int Ed Engl 2011; 50(51): 12299-12303.

5. Sancey L, Kotb S, Truillet C, Appaix F, Marais A, Thomas E, Van der Sanden $B$, Klein J, Laurent $B$, Cottier $M$, Antoine $R$, Dugourd $P$, Panczer G, Lux F, Perriat P, Motto-Ros V, Tillement O. Long-term in vivo clearance of gadolinium-based AGuIX nanoparticles and their biocompatibility after systemic injection. ACS Nano 2015; 9(3): 2477-2488. doi:10.1021/acsnano.5b00552.

6. Bridot J-L, Dayde D, Riviere C, Mandon C, Billotey C, Lerondel S, Sabattier R, Cartron G. Hybrid gadolinium oxide nanoparticles combining imaging and therapy. J Mater Chem 2009; 19(16): 2328-2335. doi:10.1039/B815836C.

7. Benachour $H$, Bastogne $T$, Toussaint $M$, Chemli $Y$, Sève $A$, Frochot $C$ Lux F, Tillement O, Vanderesse R, Barberi-Heyob M. Real-time monitoring of photocytotoxicity in nanoparticles-based photodynamic therapy: a model-based approach. PLoS One 2012; 7(11): e48617. doi:10.1371/journal.pone.0048617.

8. Kobayashi K, Usami N, Porcel E, Lacombe S, Le Sech C. Enhancement of radiation effect by heavy elements. Mutat Res 2010; 704(1-3): 123-131.

9. Rima W, Sancey L, Aloy MT, Armandy E, Alcantara GB, Epicier T, Malchère $A$, Joly-Pottuz $L$, Mowat $P$, Lux $F$, Tillement $O$, Burdin $B$,
Rivoire A, Boulé C, Anselme-Bertrand I, Pourchez J, Cottier M, Roux $S$, Rodriguez-Lafrasse C, Perriat P. Internalization pathways into cancer cells of gadolinium-based radiosensitizing nanoparticles. Biomaterials 2013; 34(1): 181-195. doi:10.1016/j.biomaterials.2012.09.029.

10. Luchette $M$, Korideck $H$, Makrigiorgos M, Tillement O, Berbeco R. Radiation dose enhancement of gadolinium-based AGulX nanoparticles on HeLa cells. Nanomedicine 2014; 10(8): 1751-1755.

11. Porcel E, Tillement O, Lux F, Mowat P, Usami N, Kobayashi K, Furusawa Y, Le Sech C, Li S, Lacombe S. Gadolinium-based nanoparticles to improve the hadrontherapy performances. Nanomedicine 2014; 10(8): 1601-1608.

12. Le Duc G, Miladi I, Alric C, Mowat $P$, Bräuer-Krisch E, Bouchet $A$, Khalil E, Billotey C, Janier M, Lux F, Epicier T, Perriat P, Roux S, Tillement $\mathrm{O}$. Toward an image guided microbeam radiation therapy using gadolinium-based nanoparticles. ACS Nano 2011; 5(12): 9566-9574.

13. Carrillo-Carrión $C$, Nazarenus $M$, Paradinas SS, Carregal-Romero $S$, Almendral MJ, Fuentes M, Pelaz B, Del Pino P, Hussain I, Clift MJ, Rothen-Rutishauser B, Liang X-J, Parak WJ. Metal ions in the context of nanoparticles toward biological applications. Curr Opin Chem Eng 2014; 4: 88-96.

14. Maeda H, Wu J, Sawa T, Matsumura Y, Hori K. Tumor vascular permeability and the EPR effect in macromolecular therapeutics: a review. J Control Release 2000; 65(1/2): 271-284.

15. Benachour $H$, Sève $A$, Bastogne $T$, Frochot $C$, Vanderesse R, Jasniewski J, Miladi I, Billotey C, Tillement O, Lux F, Barberi-Heyob M. Multifunctional peptide-conjugated hybrid silica nanoparticles for photodynamic therapy and MRI. Theranostics 2012; 2(9): 889-904.

16. Morlieras J, Dufort S, Sancey L, Truillet C, Mignot A, Rossetti F, Dentamaro M, Laurent S, Vander Elst L, Muller RN, Antoine R, Dugourd P, Roux S, Perriat P, Lux F, Coll J-L, Tillement O. Functionalization of small rigid platforms with cyclic RGD peptides for targeting tumors overexpressing $\alpha v \beta 3$-integrins. Bioconjug Chem 2013; 24(9): 1584-1597.

17. Morlieras J, Chezal J-M, Miot-Noirault E, Roux A, Heinrich-Balard L, Cohen R, Tarrit S, Truillet C, Mignot A, Hachani R, Kryza D, Antoine R, Dugourd P, Perriat P, Janier M, Sancey L, Lux F, Tillement O. Development of gadolinium based nanoparticles having an affinity towards melanin. Nanoscale 2013; 5(4): 1603-1615.

18. Elmore S. Apoptosis: a review of programmed cell death. Toxicol Pathol 2007; 35(4): 495-516.

19. Majno G, Joris I. Apoptosis, oncosis, and necrosis. An overview of cell death. Am J Pathol 1995; 146(1): 3-15.

20. Burtea C, Laurent S, Lancelot E, Ballet S, Murariu O, Rousseaux O, Port M, Vander Elst L, Corot C, Muller RN. Peptidic targeting of phosphatidylserine for the MRI detection of apoptosis in atherosclerotic plaques. Mol Pharm 2009; 6(6): 1903-1919.

21. Khan KH, Blanco-Codesido M, Molife LR. Cancer therapeutics: targeting the apoptotic pathway. Crit Rev Oncol Hematol 2014; 90(3): 200-19. doi:10.1016/j.critrevonc.2013.12.012.

22. Mohammad RM, Muqbil I, Lowe L, Yedjou C, Hsu H-Y, Lin L-T, Siegelin MD, Fimognari C, Kumar NB, Dou QP, Yang H, Samadi AK, Russo GL, Spagnuolo C, Ray SK, Chakrabarti M, Morre JD, Coley HM, Honoki K, Fujii H, Georgakilas AG, Amedei A, Niccolai E, Amin A, Ashraf SS, Helferich WG, Yang X, Boosani CS, Guha G, Bhakta D, Ciriolo MR, Aquilano K, Chen S, Mohammed SI, Keith WN, Bilsland A, Halicka D, Nowsheen S, Azmi AS. Broad targeting of resistance to apoptosis in cancer. Semin Cancer Biol 2015; 35: 1-26.

23. Fulda S. Inhibitor of Apoptosis (IAP) proteins as therapeutic targets for radiosensitization of human cancers. Cancer Treat Rev 2012; 38(6): 760-766.

24. Soon $S$, Kim $Y$, Jin $E$, Hwa S, Choi J, Park J, Hee J, Jin K, Park J, Ji H, Jung $E$, Jin J, Jin D, Suh N, Cho D, Shin J, Yeol S, Kim BM, Jeong $S$, Kyung E. Ibulocydine sensitizes human cancers to radiotherapy by induction of mitochondria-mediated apoptosis. Radiother Oncol 2014; 112(2): 295-301. doi:10.1016/j.radonc.2014.07.005.

25. Bordón $E$, Henríquez-Hernández LA, Lara PC, Ruíz A, Pinar $B$, Rodríguez-Gallego C, Lloret M. Prediction of clinical toxicity in locally advanced head and neck cancer patients by radio-induced apoptosis in peripheral blood lymphocytes (PBLs). Radiat Oncol 2010; 5: 4.

26. Laumonier C. Imagerie moléculaire: recherche de vecteurs spécifiques de l'apoptose par la méthode du phage display. PhD Thesis. University of Mons-Hainaut, 2005; p. 111.

27. Laumonier C, Segers J, Laurent S, Michel A, Coppée F, Belayew A, Vander Elst L, Muller RN. A new peptidic vector for molecular 
imaging of apoptosis, identified by phage display technology. J Biomol Screen 2006; 11(5): 537-545.

28. Van Koninckxloo A, Henoumont C, Laurent S, Muller RN, Vander EL. NMR chemical shift study of the interaction of selected peptides with liposomal and micellar models of apoptotic cells. J Biol Inorg Chem 2014; 19(8): 1367-1376.

29. Le Duc G, Roux S, Paruta-Tuarez A, Dufort S, Brauer E, Marais A, Truillet C, Sancey L, Perriat P, Lux F, Tillement O. Advantages of gadolinium based ultrasmall nanoparticles vs molecular gadolinium chelates for radiotherapy guided by MRI for glioma treatment. Cancer Nanotechnol 2014; 5: 4.

30. Moussaron A, Vibhute $S$, Bianchi A, Gündüz $S$, Kotb $S$, Sancey $L$, Motto-Ros V, Rizzitelli S, Crémillieux Y, Lux F, Logothetis NK, Tillement $\mathrm{O}$, Angelovski G. Ultrasmall nanoplatforms as calciumresponsive contrast agents for magnetic resonance imaging. Small 2015; 11(37): 4900-4909. doi:10.1002/smll.201500312.

31. Wiener EC, Brechbiel MW, Brothers H, Magin RL, Gansow OA, Tomalia DA, Lauterbur PC. Dendrimer-based metal chelates: a new class of magnetic resonance imaging contrast agents. Magn Reson Med 1994; 31(1): 1-8.

32. Burton DR, Forsen S, Karlstrom G, Dwek RA. Proton relaxation enhancement (PRE) in biochemistry - critical survey. Prog Nucl Magn Reson Spectrosc 1979; 13: 1-45.

33. Kruk D, Kowalewski J. General treatment of paramagnetic relaxation enhancement associated with translational diffusion. J Chem Phys 2009; 130(17): 1-13.

34. Helm L. Relaxivity in paramagnetic systems: theory and mechanisms. Prog Nucl Magn Reson Spectrosc 2006; 49(1): 45-64.

35. Tei L, Gugliotta G, Baranyai Z, Botta M. A new bifunctional Gd"' complex of enhanced efficacy for MR-molecular imaging applications. Dalton Trans R Soc Chem 2009; 44: 9712-9714.

36. Mieville $P$, Jaccard $H$, Reviriego F, Tripier R, Helm L. Synthesis, complexation and NMR relaxation properties of $\mathrm{Gd}^{3+}$ complexes of Mes (DO3A) 3 . Dalton Trans R Soc Chem 2011; 40(16): 4260-4267.

37. Filippi M, Remotti $D$, Botta M, Terreno E, Tei L. GdDOTAGA $\left(C_{18}\right)_{2}$ : an efficient amphiphilic $\mathrm{Gd}(\mathrm{III})$ chelate for the preparation of selfassembled high relaxivity MRI nanoprobes. Chem Commun R Soc Chem 2015; 51(98): 17455-17458.
38. Kielar F, Tei L, Terreno E, Botta M. Large relaxivity enhancement of paramagnetic lipid nanoparticles by restricting the local motions of the Gd"II chelates. J Am Chem Soc 2010; 132(23): 7836-7837.

39. Vander Elst L, Sessoye A, Laurent S, Muller RN. Can the theoretical fitting of the proton-nuclear-magnetic-relaxation-dispersion (proton NMRD) curves of paramagnetic complexes be improved by independent measurement of their self-diffusion coefficients? Helv Chim Acta 2005; 88: 574-587.

40. Laurent S, Henoumont C, Vander Elst L, Muller RN. Synthesis and physicochemical characterisation of Gd-DTPA derivatives as contrast agents for MRI. Eur J Inorg Chem 2012; 12: 1889-1915.

41. Schmidt $H$, Scholze $H$, Kaiser A. Principles of hydrolysis and condensation reaction of alkoxysilanes. J Non-Cryst Solids 1984; 63: 1-11.

42. Truillet C, Lux F, Tillement O, Dugourd P, Antoine R. Coupling of HPLC with electrospray ionization mass spectrometry for studying the aging of ultrasmall multifunctional gadolinium-based silica nanoparticles. Anal Chem 2013; 85(21): 10440-10447.

43. Frangioni J. In vivo near-infrared fluorescence imaging. Curr Opin Chem Biol 2003; 7(5): 626-634.

44. Parmelee DJ, Walovitch RC, Ouellet HS, Lauffer RB. Preclinical evaluation of the pharmacokinetics, biodistribution, and elimination of MS-325, a blood pool agent for magnetic resonance imaging. Invest Radiol 1997; 32(12): 741-747.

45. Henrotte V, Laurent S, Gabelica V, Vander Elst L, Depauw E, Muller RN. Investigation of non-covalent interactions between paramagnetic complexes and human serum albumin by electrospray mass spectrometry. Rapid Commun Mass Spectrom 2004; 18(17): 1919-1924.

46. Laurent S, Vander Elst L, Muller RN. Comparative study of the physicochemical properties of six clinical low molecular weight gadolinium contrast agents. Contrast Media Mol Imaging 2006; 1(3): 128-137.

\section{SUPPORTING INFORMATION}

Additional supporting information can be found in the online version of this article at the publisher's website. 